\title{
Peptide-Based Vaccines for Neurodegenerative Diseases: Recent Endeavors and Future Perspectives
}

\author{
Vyronia Vassilakopoulou ${ }^{1, *} \mathbb{( D}$, Chrysoula-Evangelia Karachaliou ${ }^{1} \mathbb{D}$, Alexandra Evangelou ${ }^{2} \mathbb{D}$, Christos Zikos $^{1}$ \\ and Evangelia Livaniou $1, * \mathbb{D}$ \\ 1 Immunopeptide Chemistry Lab., Institute of Nuclear \& Radiological Sciences \& Technology, Energy \& \\ Safety (INRASTES), National Centre for Scientific Research "Demokritos", Patr. Grigoriou E' \& 27 Neapoleos \\ St., 15341 Agia Paraskevi, Greece; xrisak15@rrp.demokritos.gr (C.-E.K.); chzikos@yahoo.gr (C.Z.) \\ 2 Department of Wine, Vine and Beverage Sciences, University of West Attica, 12243 Athens, Greece; \\ aevangelou@uniwa.gr \\ * Correspondence: vyrwniavassil@hotmail.com (V.V.); livanlts@rrp.demokritos.gr (E.L.)
}

check for

updates

Citation: Vassilakopoulou, V.; Karachaliou, C.-E.; Evangelou, A.; Zikos, C.; Livaniou, E. Peptide-Based Vaccines for Neurodegenerative Diseases: Recent Endeavors and Future Perspectives. Vaccines 2021, 9, 1278. https://doi.org/10.3390/ vaccines 9111278

Academic Editor: Hans-Peter Hartung

Received: 8 October 2021

Accepted: 30 October 2021

Published: 4 November 2021

Publisher's Note: MDPI stays neutral with regard to jurisdictional claims in published maps and institutional affiliations.

Copyright: (C) 2021 by the authors. Licensee MDPI, Basel, Switzerland. This article is an open access article distributed under the terms and conditions of the Creative Commons Attribution (CC BY) license (https:/ / creativecommons.org/licenses/by/ $4.0 /)$.

\begin{abstract}
The development of peptide-based vaccines for treating human neurodegenerative diseases has been the eventual aim of many research endeavors, although no active immunotherapies have been approved for clinical use till now. A typical example of such endeavors is the effort to develop vaccines for Alzheimer's disease based on the beta-amyloid peptide, which continues to be intensively investigated despite previous setbacks. In this paper, recent developments in peptide-based vaccines which target beta-amyloid as well as tau protein and $\alpha$-synuclein are presented. Particular focus has been directed toward peptide epitopes and formulation systems selected/developed and employed to enhance vaccine efficacy and safety. Results from both, human clinical trials and animal preclinical studies conducted mainly in transgenic mice have been included. Future perspectives on the topic are also briefly discussed.
\end{abstract}

Keywords: vaccines; neurodegenerative diseases; Alzheimer's disease; beta-amyloid peptide; tau protein; $\alpha$-synuclein; peptide epitopes; vaccine formulation; clinical trials; animal preclinical studies

\section{Introduction}

Neurodegenerative diseases are associated with a progressive loss of neurons in the central nervous system (CNS) and are characterized by severe clinical deficits, especially cognitive, motor, and psychiatric ones. Since aging is among the strongest risk factors causing their development, neurodegenerative diseases are considered a big public health problem with high socioeconomic impact in the developed world, where people's life span has been continuously increased during the last decades. The most common neurodegenerative disease is Alzheimer's disease (AD), while other well-known neurodegenerative diseases include Parkinson's disease (PD), amyotrophic lateral sclerosis (ALS), Huntington's disease (HD), etc. [1].

AD, first described by Dr. Alois Alzheimer in 1906 [2], is clinically characterized by memory, psychological and psychiatric deficits as well as language impairment, which progressively lead to practical difficulties in executing a normal everyday life and, eventually, to death [3,4]. As estimated, people with AD worldwide are currently around 40 million and this number is expected to continuously grow. AD and neurodegenerative diseases, in general, are complex and very heterogeneous. Aging seems to be the main risk factor, since the occurrence of AD increases substantially with age and becomes almost double every 5 years after the age of 65 [5]. Nevertheless, other reasons that may cause AD have been reported in the literature, such as abnormal nutrition, malfunction of the immune system, infectious agents, serious brain damage and degeneration of crucial anatomical pathways, mitochondrial dysfunction that may cause metabolic disorders, vascular factors that may affect the functioning of the blood-brain barrier, or exposure to environmental 
toxic substances [6,7]. On the other hand, specific genetic abnormalities, including mutations of amyloid precursor protein and presenilin genes as well as allelic variation in apolipoprotein E (ApoE), have also been associated with AD.

$\mathrm{AD}$ appears in two forms: sporadic $\mathrm{AD}$, which is late-onset, i.e., symptoms begin after the age of 65 , and represents the vast majority of $\mathrm{AD}$ cases $(\sim 95 \%)$, and familial $\mathrm{AD}$, an early-onset and dominantly inherited disease, which accounts for a low percentage $(\sim 5 \%)$ of $\mathrm{AD}$ cases [5]. Although age is the major risk factor for sporadic $\mathrm{AD}$, the presence of ApoE- $\varepsilon 4$ genetic polymorphism highly increases the possibilities of developing the disease in persons older than 65 years [8]. Moreover, a large genome meta-analysis of clinically diagnosed late-onset $\mathrm{AD}$ cases confirmed 20 previously reported risk loci and also identified some new ones [5], associated e.g., with lipid metabolism and immunity [3]. On the other hand, familial AD affects younger individuals and is associated with mutated forms of the amyloid precursor protein (APP) and the core proteins of $\gamma$-secretase complex, presenilin 1 and presenilin 2 (PS1 and PS2), the presence/function of which result in accumulation of amyloid $\beta$ peptide $(A \beta)$ and formation of extracellular amyloid plaques $[8,9]$. In general, according to the well-known "amyloid cascade hypothesis" [10], under certain circumstances neurotoxic $\mathrm{A} \beta$ can be produced, accumulated/aggregated, and ultimately damage neurons, thus leading to dementia [3]. Though the pathogenesis of AD has not yet been completely understood, the amyloid cascade hypothesis remains the best known and most widely accepted theory proposed until now. In addition to the extracellular amyloid plaques composed of $\mathrm{A} \beta, \mathrm{AD}$ is also characterized by the formation of intracellular neurofibrillary tangles composed of the microtubule-associated protein tau in an abnormally phosphorylated form [11]. Thus, abnormal $A \beta$ and tau aggregates have been considered the most typical characteristic of $\mathrm{AD}[1,12]$. Though it is not clear how these aberrant oligomers/aggregates can lead to neurodegeneration, synaptic dysfunction and neuroinflammation they seem to cause might be the reason $[13,14]$. One other protein, i.e., $\alpha$-synuclein $(\alpha$-syn), has been initially associated with another well-known neurodegenerative disease, i.e., $\mathrm{PD}$, along with specific neurodegenerative diseases, such as dementia with Lewy bodies (DLB); $\alpha$-syn is the main component of Lewy bodies, i.e., the most evident histopathological characteristic of PD and all of the aforementioned diseases $[15,16]$. In addition to PD, $\alpha$-syn has been lately associated with AD, too [17]. Misfolding/accumulation of additional proteins, e.g., superoxide dismutase 1 and huntingtin, in specific brain regions has been related to the onset/progress of neurodegenerative diseases, such as ALS and HD, respectively $[1,14,18]$. To further support the linkage between certain proteins/peptides and neurodegenerative diseases, focusing on $A D$, we should mention that cerebrospinal fluid (CSF) levels of $\mathrm{A} \beta$ - and tau- related biomarkers have been widely employed for confirming AD diagnosis, along with positive amyloid-PET scans $[5,19]$. Moreover, pathological features related to Lewy bodies, mainly composed of $\alpha$-syn, have been reported to occur in brains of patients with $\mathrm{AD}$, while the elevation of $\alpha$-syn CSF- levels in AD patients has been associated with clinical decline [17].

Treatment of AD is a very important issue for health care systems [5]. Until recently, treatment for $\mathrm{AD}$ patients relied on the pharmacological intervention of cholinergic and glutamatergic neurotransmission. Thus, a few drugs for AD have been approved by the US Food and Drug Administration (FDA), including donepezil, rivastigmine, and galantamine (cholinesterase inhibitors), memantine (an $\mathrm{N}$-methyl-D-aspartate receptor partial antagonist), and a combination of donepezil and memantine. All these drugs, however, have limited effectiveness and they do not reverse the progression of the disease or improve cognitive dysfunction, but they rather delay the deterioration of $\mathrm{AD}$ symptoms for a limited time period [8]. Recently, a fully human monoclonal antibody targeting $A \beta$, aducanumab, has been approved by the FDA, although there has been some controversy concerning the overall efficacy of this passive immunotherapeutic agent [20-24]. Thus, it is of utmost importance to investigate and develop further therapeutic/preventive strategies to fight $\mathrm{AD}$ and other neurodegenerative diseases [3]. 
Vaccination is a highly effective strategy followed in the Public Health Sector as a means to defeat especially infectious diseases. Vaccines induce immunogen-specific clones of B and T lymphocytes, which recognize different regions of the immunogen (usually a protein or a suitable protein-conjugate), i.e., peptide epitopes. B cells recognize "exposed" parts of the immunogen, which may be linear or conformational and are known as B cell epitopes, while $\mathrm{T}$ cells recognize linear peptide sequences of the immunogen ( $\mathrm{T}$ cell epitopes). Differentiation of B cells into mature plasma cells leads to the production of large amounts of antibodies, which recognize the same B-cell epitope that has caused B-cell stimulation in the first place; B and T cells may differentiate into memory cells, which ensure enhanced immune response after subsequent exposure to the same immunogen. Several attempts to exploit the power of the immune system and develop active immunotherapies (i.e., vaccines) against AD have been made during the last twenty years [5], while passive immunotherapy strategies, in which specific antibodies against the biomolecular target, such as aducanumab, are directly administered to the host organism have also been followed, in the frame of preclinical studies and/or clinical trials with human subjects [14]. Immunization against $\mathrm{A} \beta$ as an active immunotherapy for $\mathrm{AD}$ has its origins in the idea that antibodies targeting $A \beta$ may block its aggregation and, consequently, prevent the disease progression. One should take into consideration, however, that $A \beta$ is a self-peptide that may either be non-immunogenic or induce a damaging autoimmune reaction [5] and, thus, efficacy and safety of active immunotherapies for AD are major issues to be addressed. Nevertheless, and despite no vaccine for AD has been approved till now, the basic concept is still considered promising and several vaccine candidates with improved characteristics are being currently studied [5]. All A $\beta$-vaccines so far reported may be considered peptidebased vaccines, since $A \beta$ consists of less than 45 amino acids (see Section 2.2.1) and is, therefore, thought to be a peptide rather than a protein [25]; on the other hand, vaccines targeting tau and $\alpha$-syn can be considered peptide-based, if specific peptide epitopes, instead of the intact parental protein, have been employed for their development.

The goals of the present work can be summarized as follows: (i) to underline the continuous interest in the field of developing active immunotherapy approaches based on appropriately selected/designed peptide epitopes of specific biomolecular targets (A $\beta$, tau and $\alpha$-syn) which have been associated with neurodegenerative diseases, (ii) to list the most important endeavors in this field, including recent studies, not mentioned in previous review papers, (iii) to highlight specific factors, e.g., the formulation systems used or the experimental conditions employed during preclinical evaluation (animal models/vaccination schemes, etc.), which may affect the final outcome. Future perspectives in the field are also briefly mentioned.

\section{A $\beta$, Tau, and $\alpha$-Syn as Biomolecular Targets of Peptide-Based Vaccines for Neurodegenerative Diseases}

\subsection{Biomolecular Targets of Vaccines for Neurodegenerative Diseases}

Significant efforts toward the development of active immunotherapies/vaccines for neurodegenerative diseases have focused on targeting pathologic species of $A \beta$, tau, and, to a lesser extent $\alpha$-syn since aberrant aggregation of these biomolecules is considered to play a major role in the disease pathophysiology [26]. Immunization targeting these peptides/proteins has been expected to result in the generation of antibodies that might facilitate clearance or prevent the formation of neurotoxic forms of the parental targets [4]. However, there are some issues that should be taken into account and appropriately addressed, in order to achieve optimal results: As already mentioned, $\mathrm{A} \beta$, as well as tau and $\alpha$-syn, are probably conceived as "self" molecules by the host organism; thus, they may be either non-immunogenic or induce a detrimental auto-immune reaction [5] and this aspect should be carefully taken into consideration when designing such a vaccine. Another issue is how the antibodies induced after immunization can cross the blood-brain barrier and access the pathologic spots [4]. However, antibodies against $A \beta$ that had been peripherally administered were reported to enter CNS in mouse models of AD, and in human subjects participating in clinical trials $[5,27]$. In vivo access of the pathologic loci 
is even more complicated, when intracellular proteins are targeted, such as tau. Previous experimental data have shown, however, that intracellular "neurodegenerative" proteins may be also present extracellularly [14]. Moreover, recent technological advances, especially in the field of delivery systems, have facilitated successful in vivo accessibility of pathologic targets and stimulated new efforts to develop active immunotherapies targeting $A \beta$, tau, and $\alpha$-syn [14].

According to recently accumulated evidence, neurotoxic species of $A \beta$, tau, and $\alpha$-syn may exert their toxicity at least in part through binding to cellular prion protein $(\mathrm{PrP})$ on the surface of neurons [28-30]. Thus, PrP rather than individual disease-associated proteins might be (immuno)therapeutically targeted. Moreover, a few additional molecular targets have been reported in the literature, e.g., TAR DNA-binding protein 43 (TDP-43), dipeptide repeat proteins (DPRs), superoxide dismutase 1 , and huntingtin protein $[1,14,18,31,32]$, but little data on the development of vaccines against these targets are available.

\subsection{A $\beta$, Tau, and $\alpha$-Syn as Targets of Vaccines for Neurodegenerative Diseases}

\subsection{1. $\mathrm{A} \beta$}

$A \beta$, which is the main component of the extracellular amyloid plaques in the $A D$ brain, exists in two main forms, composed of 40 amino acids [A $\beta(1-40)$ ] and 42 amino acids [A $\beta(1-42)]$, respectively [3]. A $\beta$ is formed through proteolysis of APP by $\beta$ - and $\gamma$-secretase. More specifically, APP, which is a membrane protein occurring in many tissues and particularly concentrated in neuronal synapses, undergoes proteolytic degradation by $\alpha-, \beta-$, and $\gamma$-secretases. APP proteolysis by $\alpha$-secretase leads to products that are not amyloidogenic or toxic, while proteolysis by $\beta$ - and subsequently $\gamma$ - secretase results in the formation of the amyloidogenic APP fragments, $A \beta(1-40)$ and $A \beta(1-42)$, the latter of which seems to aggregate more readily and be more toxic [3]. Mutations in APP or APP gene duplication as well as mutations in the core proteins of $\gamma$-secretase complex, PS1 and PS2, may increase $A \beta$ aggregation into oligomers, amyloid fibrils, and plaques, all of which can be cytotoxic [3]. In general, according to the amyloid cascade hypothesis, an imbalance between formation and clearance of $A \beta$ is considered critical for developing $\mathrm{AD}[4,5,10]$. The exact mechanisms through which different $A \beta$ species contribute to neurotoxicity remain largely unknown, but recent evidence suggests that soluble oligomers are the most neurotoxic [4]. Structures/shapes of $A \beta$ monomers, oligomers, and fibrils have been extensively studied in the last few years with various experimental techniques [33].

\subsubsection{Tau}

Although pathologic $\mathrm{A} \beta$ is the prevalent toxic event in $\mathrm{AD}$ according to the amyloid cascade hypothesis, clearance of $A \beta$ alone may be insufficient to stop/delay the disease progress especially in the later stages of $\mathrm{AD}$, while accumulating evidence shows that pathologic tau may also correlate with disease pathogenesis and progression [34]. Interestingly, there may be a link between $A \beta$ and tau in $A D$ pathophysiology, since $A \beta(1-42)$ oligomers have been reported to cause, among other toxic effects, tau hyperphosphorylation [5]. Tau is a microtubule-associated protein that is highly expressed in neurons. There are six isoforms of tau protein, which vary in size from 352 to 441 amino acid residues. The different isoforms contain three or four tubulin-binding repeats (3R, 4R) also known as microtubule-binding repeats (MTBRs) of 31 or 32 amino acids each in their C-terminus and one, two, or no inserts of 29 amino acids each in the N-terminus of the molecule. Primary sequence analysis has shown that tau consists of four distinct regions: the $\mathrm{N}$-terminal domain (NTD), the proline-rich domain (PRD), the microtubule-binding region (MTBR) and the C-terminal domain (CTD). Two aggregation-prone hexapeptide motifs have been identified, (275-280) and (306-311), which are located on the R2 repeat and R3 repeat of MTBR, respectively [35]. Tau filaments from AD have been studied with cryogenic electron microscopy [36]; moreover, filaments formed in vitro from the truncated tau (297-391) have been reported to resemble paired helical filaments found in AD brains at the macromolecular level [37]. Tau is post-translationally modified through phosphorylation and bears 
around 80 potential phosphorylation sites, which are targets of several kinases and phosphatases [4]. Hyperphosphorylation, as well as truncation of Tau, are thought to contribute to protein misfolding and subsequent formation of intracellular neurofibrillary tangles (NFTs), which are a major hallmark lesion of AD and other neurodegenerative diseases, especially frontotemporal lobar degeneration diseases [38]. Abnormal phosphorylation at specific amino acids, such as $\operatorname{Ser}^{199}, \mathrm{Ser}^{202} / \mathrm{Ser}^{205}, \mathrm{Thr}^{231}$, and $\mathrm{Ser}^{262}$, has been associated with the formation of pre-tangles in the neurons, while additional phosphorylation sites, such as Ser ${ }^{422}$ and Ser ${ }^{396}$ seem to appear later in disease progression $[39,40]$.

\subsection{3. $\alpha$-Syn}

$\alpha$-Syn is a presynaptic protein reported to be involved in endosomal formation and vesicle release at the synapse $[14,41,42]$. At least three isoforms of synuclein are produced through alternative splicing. The main and most investigated form is the full-length protein of 140 amino acids. $\alpha$-Syn can be divided into three distinct regions: an amphipathic $\mathrm{N}$ terminal region (residues 1-60), a central hydrophobic region (residues 61-95) known as non-A $\beta$ component (NAC), which plays a central role in the aggregation of $\alpha$-syn, and a C-terminal region (residues 96-140), which is acidic, unstructured and proline-rich [17]. Although the overall secondary structure of $\alpha$-syn has not yet been fully determined, the $\mathrm{N}$-terminal and NAC regions are believed to fold together into $\alpha$-helices [17]. The acidic charge on the C-terminus of $\alpha$-syn may provide higher hydrophilicity, in comparison with the $\mathrm{N}$-terminus, thus allowing C-terminus to be better exposed and consequently be a better target for immunotherapy [43]. As reported, pathologic $\alpha$-syn exists in insoluble forms that can aggregate into oligomers and fibrillar structures. Accumulation of pathologic $\alpha$-syn in the form of Lewy bodies and Lewy neurites is a characteristic of several neurodegenerative diseases, especially PD [44-46]. As already mentioned, $\alpha$-syn has been lately implicated in AD pathophysiology, as well [17].

\subsection{Other Neurotherapeutic Strategies Targeting $A \beta$, Tau, and $\alpha$-Syn}

\subsubsection{Passive Immunotherapies}

Along with the attempts to develop active immunotherapies targeting $A \beta$, many passive anti-A $\beta$ immunotherapies have been investigated [5,47]. As recently reported [5], four monoclonal anti-A $\beta$ antibodies have entered a phase III clinical trial: aducanumab, BAN2401, gantenerumab, and solanezumab. Aducanumab, a human IgG1 antibody selected through screening of memory $B$ cells of healthy aged people which selectively targets soluble oligomers and insoluble fibrils of $A \beta$, has been recently approved as an immunotherapy for AD by the FDA, though there has been some controversy concerning its efficacy [20-24]. Candidate passive immunotherapies targeting tau [14,47] and $\alpha$-syn [46] have been also reported in the literature.

\subsubsection{Peptides with Putative Action on Neurotoxic Aggregate-Species}

Additional approaches against neurodegenerative diseases have been recently reported, which often use specific peptides to target neurotoxic aggregates, e.g., of $A \beta$ or $\alpha$-syn [48,49]; though these approaches are out of the scope of the present paper, we briefly refer here to humanin $(\mathrm{HN})$, as an indicative example of neurotherapeutic peptides that may prevent $\mathrm{A} \beta$ aggregation. $\mathrm{HN}$ is a 24-mer peptide [50], probably of mitochondrial origin. As previously shown by our team with Circular Dichroism and Nuclear Magnetic Resonance studies [51], HN is unstructured and flexible in aqueous solutions, while it adopts a helical structure $\left(\mathrm{Gly}^{5}-\mathrm{Leu}^{18}\right)$ in a less polar environment; structural findings suggest that unstructured HN may interact with different receptors, while in its helical conformation it may cross membranes and subsequently participate in more specific interactions. $\mathrm{HN}$ was previously identified to interact with $\mathrm{A} \beta$, being capable of transforming fibrillar $\mathrm{A} \beta(1-40)$ to an amorphous peptide [52]. Thus, the interaction of $\mathrm{HN}$ with $\mathrm{A} \beta$ might explain protective functions of $\mathrm{HN}$ against neurotoxicity of $A \beta$ [53]. 
3. A $\beta-$, Tau- and $\alpha$-Syn Peptide Epitopes Used in Peptide-Based Vaccines for Neurodegenerative Diseases

\subsection{Peptides Epitopes: General Concepts}

Peptide vaccines are based on specific B- (and T-) cell peptide epitopes. The epitope choice is a crucial step in the vaccine design, since the peptide epitopes should be able to induce strong, long-lasting humoral and/or cellular immunity against the biomolecular target [54].

A B-cell epitope is a specific fragment of the antigen/immunogen which is recognized by the B-cell receptors present on the surface of B-cells of a unique clone; B-cell epitopes are subsequently bound to the antibodies generated upon B-cell stimulation/maturation. B-cell epitopes can be linear and may be as short as pentapeptides, but they are mostly conformational $[25,55]$. T-cell epitopes are linear peptide fragments that can be bound to major histocompatibility complex proteins (MHC I, MHC II), through which they are presented on the surface of appropriate cells and subsequently recognized by T-cell receptors on CD8+ (cytotoxic T-cells) and CD4+ (helper T-cells), respectively [25,55]. Cytotoxic T-cell epitopes are usually 8- to 12-mer peptides, whereas helper T-cell epitopes (Th) are usually 12- to 17-mers [5,55].

Identifying epitopes in disease-associated immunogens is of great interest for designing epitope-based vaccines. NMR and X-ray crystallographic methods have been used for this purpose. T-cell and B-cell epitope computational prediction methods and tools (immunoinformatics), which are faster and less expensive than NMR and X-ray crystallography, have also been employed [55-57]. Moreover, antibodies have been often utilized as a template for vaccine design, following the concept that if a particular epitope is related to certain B- cell responses, then it will probably induce similar responses when administered in the form of a vaccine [4].

As already mentioned, the most significant efforts to develop peptide-based vaccines for $\mathrm{AD}$ and other neurodegenerative diseases have focussed on targeting specific epitopes of $\mathrm{A} \beta$, tau, and $\alpha$-syn (Sections 3.2-3.4, respectively). Special examples of how peptide-based vaccines may be advantageous over the ones based on the intact polypeptide/proteins are extensively presented (e.g., in second-generation A $\beta$ vaccines).

\subsection{Peptide Epitopes Used in A $\beta$-Vaccines}

The first therapeutic approach for AD through active immunization was based on full-length pre-aggregated $A \beta(1-42)$ [58]. However, the first clinical trials with the socalled AN1792 vaccine (Table 1), based on A $\beta(1-42)$, failed, since meningoencephalitis appeared in some of the immunized AD patients; this severe side-effect was attributed to a cell-mediated inflammatory response caused by both, T cell epitopes of $A \beta(1-42)$ and the adjuvant used (QS-21, Section 4.3.3). Moreover, the AN1792 vaccine induced rather insufficient antibody titer, probably due to the weak immunogenicity of $A \beta[3,5,59]$.

Despite the serious safety issues and the rather low efficacy, results of the initial clinical trials with AN1792 along with follow-up data inspired further research toward the development of vaccines targeting $A \beta$. Special efforts were focused on how to avoid autoreactive $T$ cells against $A \beta$ and to generate relatively high titers of antibodies. Biochemical assays have identified the first $N$-terminal 15 amino acids of $A \beta$ as the site of the principal B-cell epitope [60], whereas the T-cell epitopes are believed to localize in the $\mathrm{C}$-terminus. Thus, second-generation $\mathrm{A} \beta$ vaccines were developed by selecting peptide fragments of the $N$ terminus of $A \beta$, and suitably formulating [61] these fragments with foreign carriers/delivery systems and adjuvants, so as to enhance the immunogenicity of B-cell epitopes $[4,5]$.

Second-generation $A \beta$ vaccines that have subsequently been tested in clinical trials (Table 1) include CAD106, ACC-001 (vanutide cridificar), Lu AF20513, UB-311, ACI-24, V-950, ABvac40, AD01, AD02, and AD03 [3-5,14,61,62]. CAD106 [1,3-5,14,61-64] is based on the first 6 amino acids of A $\beta$, ACC-001 [1,3,5,14,61,62,65] is based on the first 7 amino acids, Lu AF20513 [3-5,61,62] is based on the first 12 amino acids, UB-311 [3-5,14,61,62,66] 
is based on the first 14 amino acids, and ACI- $24[1,3,5,14,61,62]$ is based on the first 15 amino acids, whereas $\mathrm{V}-950$ also employs an $\mathrm{N}$-terminal $\mathrm{A} \beta$ peptide fragment $[3,61,62]$, reported to be $A \beta(1-15)$ [66]. On the other hand, it should be noticed that $A B v a c 40$ vaccine $[1,3-5,14,61,67]$ has employed a short $C$-terminal fragment of $A \beta$, i.e., $A \beta(33-40)$, based on the observation that antibodies raised against the $C$-terminus of $A \beta$ seem to affect $\mathrm{A} \beta$ aggregation $[67,68]$. Moreover, AD01 [3], AD02 and AD03 [3,5,14,61,62,69] are based on epitopes mimicking the $A \beta N$-terminus [3,62].

Though none of the second-generation vaccines have induced meningoencephalitis, a few antibody-mediated adverse effects, such as vasogenic edema and microhemorrhages, were reported. Moreover, these vaccines have not led to any substantial clinical benefit [70] and, as reported, clinical trials are currently ongoing only for a few of them, i.e., CAD106, ACI-24, UB-311, and ABvac40 [5].

In addition to vaccines that have undergone clinical trials, many other peptide-based $A \beta$-vaccines have been developed and tested in rodents, mostly transgenic mice. Most of these vaccines focus on the $A \beta N$-terminus. More specifically (Table 1), A $\beta(3-10)$ [70-72] and $A \beta(1-6)$ were among the peptide epitopes used [73]; different copy numbers of the latter were used in another attempt to develop new $A \beta$ - vaccines [74]. In addition, $A \beta(1-6)$ and $A \beta(1-15)$ were used for the synthesis of 4-branched multiple-antigen peptides (MAP) ${ }_{4}$ and subsequently administered to mice to develop $A \beta$ specific antibodies [75]. $A \beta(1-15)$ was also used in a cholera toxin B subunit/silkworm pupa vaccine [76] as well as in a yeast-based vaccine (Y-5A15) [77]. A $\beta(1-11)$ was used in a combination vaccine (AV1959R/AV-1980R) targeting both $A \beta$ and tau [78]. Moreover, $A \beta(1-11)$ was used in a DNA vaccine (AB-1959D), which encoded for a fusion protein containing three copies of $A \beta(1-11)$ [79]. $A \beta(1-11)$ was also part of a fusion protein containing the bacterial protein domain E2, (1-11)E2, which was further used in animal vaccination [80]. Vaccines based on small cyclic peptides, i.e., cyclo[A $\left.\beta(22-28)-\mathrm{YNGK}^{\prime}\right]$, cyclo[A $\left.\beta(23-29)-\Upsilon N G K^{\prime}\right]$, and cyclo[A $\left.\beta(22-29)-\mathrm{YNGK}^{\prime}\right]$, mimicking the specific molecular turn in the structure of oligomeric $A \beta$ were reported [81]. In a recent paper, a series of several synthetic $A \beta$ epitopepeptides, linear or cyclic, including $A \beta(1-6), A \beta(1-6)_{3}, A \beta(1-15)$, cyclo[A $\left.\beta(1-7)\right]$, cycloEP1 and cycloEP2 (where EP1 and EP2 are special peptide epitopes of A $\beta$ oligomers, selected with phage display from random peptide libraries), have been appropriately formulated and subsequently tested in animal preclinical studies [40]. Interestingly, intact $A \beta(1-42)$ has been specifically formulated and tested in animal preclinical studies, without inducing neuroinflammation [82]. Moreover, a DNA vaccine based on A $\beta(1-42)$ trimer and targeting amyloid plaques and tau protein was also reported [83]. Since soluble $A \beta$ oligomers and protofibrils are now considered as the most toxic forms of $A \beta$ and a discontinuous conformational epitope formed by soluble $A \beta$ oligomers might be the ideal target of an $A \beta$ vaccine $[18,61,68]$, one more vaccine (AOE1) based on specific conformational epitope(s) of $\mathrm{A} \beta$ oligomers as an immunogen has been recently described [84].

\subsection{Peptide Epitopes Used in Tau-Vaccines}

Targeting therapeutically relevant epitopes on tau proteins in a safe manner is a very interesting and highly challenging objective [11]. Identification of the most effective tau epitopes for vaccine development is still a matter of debate since many modifications of tau (phosphorylation, truncation, oligomerization, etc.) have been demonstrated to contribute to neurodegenerative disease pathogenesis.

Two tau vaccines have been tested in clinical trials with AD patients, AADvac1 and ACI-35 (Table 1). AADvac1 [1,3,4,14,61,85-88] is based on tau(294-305). This sequence was identified through experimental immunization of transgenic mice with mis-disordered tau(151-391/4R) followed by isolation of antibodies and screening for in vitro disruption of tau-tau interaction [4]; tau(294-305) epitope was determined by X-ray crystallography [89] and then tested in an AD-animal model [90]. AADvac1 induces specific antibodies targeting three or four conformational epitopes on mis-disordered tau protein with an exposed microtubule-binding repeat domain (MTBR), which seems to be actively involved in tau 
aggregation $[14,86,87]$. Initial clinical trials have proved vaccine safety, thus encouraging further trials with larger numbers of participants [4]. On the other hand, vaccine ACI-35 [1,3,4,14,86,88] is based on the synthetic C-terminal peptide tau(393-408); more specifically, it consists of 16 copies of the aforementioned tau fragment, phosphorylated at $\operatorname{Ser}^{396}$ and $\operatorname{Ser}^{404}[4,11,86]$. The rationale is that the antibodies induced will attack tau conformers containing the pathologic phosphorylation residues rather than the nonpathologic tau species [88]. A few years ago, a phase $\mathrm{Ib} / \mathrm{IIa}$ trial was conducted to validate the safety, tolerability, and immunogenicity of an advanced version of this vaccine, i.e., ACI-35.030 [1,3,14].

In addition to the vaccines that have undergone clinical trials, other tau-vaccines have been developed and tested in animal preclinical studies (Table 1). More specifically, the N-terminal region tau(2-18), also known as phosphatase activating domain (PAD), has been appropriately formulated and used for vaccinating transgenic mice, since PAD becomes exposed in pathological tau and plays an essential role in tau polymerization. $[34,78,91,92]$. The $\mathrm{N}$-terminal region of tau is also the target of many passive anti-tau immunotherapies [11,93]. On the other hand, the epitope tau(294-305), i.e., that used in vaccine AADvac-1, has been appropriately formulated (T294-HBcVLP) and the vaccine was tested in AD transgenic mice [94].

Many vaccines recently tested in animals target phosphorylated tau (phospho-tau) epitopes [95-98]. Pathologic phosphorylation is a crucial event in tau pathogenicity and it is believed that by eliminating such toxic tau species, the degenerative process may be blocked [99]. For example, phosphorylation of Ser ${ }^{396}$ may lead to a switch from an $\alpha$-helix to a $\beta$-strand motif that misfolds tau and stabilizes a toxic conformation. Therefore, early prevention of Ser ${ }^{396}$-phosphorylation through immunotherapy might prevent the spreading of this pathologic tau species [93].

A series of peptides from tau protein, including the so-called T294, pTau(396-404), and pTau422, have been used in a recent preclinical study. Two phosphorylated epitopes of tau, pTau(396-404) and pTau422, along with T294, i.e., tau(294-305), were appropriately formulated using the so-called SpyCatcher/SpyTag technology and administered to AD transgenic mice; as shown, the vaccine based on pTau 422 peptide alleviated cognition deficits and blocked neuropathology progression in animals [40].

In another recent preclinical study, three phosphorylated tau peptides (pTau peptides) bearing a combination of up to four AD-related epitopes were designed and synthesized. pTau30 has been phosphorylated at residues $\mathrm{Ser}^{202} / \mathrm{Thr}^{205} / \mathrm{Ser}^{238} / \mathrm{Ser}^{262}$; pTau31 has been phosphorylated at residues $\mathrm{Ser}^{202} / \mathrm{Thr}^{205} / \mathrm{Ser}^{396} / \mathrm{Ser}^{404}$; pTau35 has been phosphorylated at $\operatorname{Ser}^{238} / \mathrm{Ser}^{262} / \mathrm{Ser}^{396} / \mathrm{Ser}^{404}$. Mice immunization has shown that only pTau31-induced antibodies could recognize all carried four epitopes. Furthermore, pTau31 could neither elicit non-phosphorylated Tau31-specific antibodies nor stimulate tau-specific T-cell activation [97]. Moreover, other tau peptides containing tauopathy-related phosphorylated epitopes, i.e., $\operatorname{tau}(195-213) / \mathrm{p} 202 / 205$, tau(207-220)/p212/214, and tau(224-238)/p231, were used for animal vaccination in preclinical studies, leading to results supporting the alleviation of both, tau and $A \beta$ pathologies [95]. In a previous work, tau(379-408)/p396/404 was tested in preclinical studies leading to a reduction in both, tau and $\mathrm{A} \beta$ pathologies $[1,100]$.

Overall, it should be noticed that, as mentioned, tau contains more than eighty potential serine, threonine, and tyrosine phosphorylation sites, and many phosphorylated epitopes of tau are also present in healthy human brains; therefore, careful consideration is needed as to which epitope will be chosen and targeted [88,98].

\subsection{Peptide Epitopes Used in $\alpha$-Syn Vaccines}

In order to identify surface-exposed epitopes of in vitro and in vivo formed aggregates of $\alpha$-syn, polyclonal IgY antibodies were raised against short linear peptides of the $\alpha$-syn molecule and used in suitable immunochemical studies [101]. The N-terminal $\alpha$-syn(1-10) and C-terminal $\alpha$-syn (90-140) fragments were found to be exposed with ELISA experiments [101]. On the other hand, the C-terminal epitopes $\alpha$-syn(111-140)/ $\alpha-\operatorname{syn}(121-140)$ 
were recognized by human anti- $\alpha$-syn antibodies isolated from PD patients [102]. Moreover, the secondary structural features of $\alpha$-syn in an aqueous environment have been studied with computer simulation [103]. All this information might be further exploited when designing novel peptide-based vaccines targeting $\alpha$-syn.

The only $\alpha$-syn vaccines that have been tested in clinical trials (Table 1 ) are based on short synthetic peptide fragments that mimic C-terminal residues of $\alpha$-syn(110-130) (PD01A and PD03A, Affiris) [14,46,104-108]. PD01A and PD03A have shown promising efficacy and safety in phase I clinical trials with multiple system atrophy (MSA) patients. Interestingly, peptides from the C-terminus of $\alpha$-syn have been reported to induce in vitro both helper and cytotoxic T cell autoimmune responses in patients with PD [109]; the still adequately good safety features of PD01A/PD03A, which target the $\alpha$-syn C-terminus, may be attributed to two main reasons, (i) the C-terminal peptides used are too short for inducing a T-cell autoimmune response, and, (ii) the vaccines developed do not bear the exact native epitope, but rather a mimicking sequence $[14,46,108]$. In July 2021, the AC Immune Company announced that it would begin a phase II clinical trial of an optimized formulation of the PD01 vaccine, called ACI-7104 [108].

In addition to the aforementioned vaccines tested in clinical trials, other $\alpha$-syn vaccines have been developed and evaluated in preclinical studies. The first relevant efforts used recombinant human $\alpha$-syn for vaccinating a mouse model of PD [110]. Since then, a few peptide-based vaccines targeting $\alpha$-syn have been developed and shown efficacy in animal preclinical studies [105], including those shown in Table 1 [43,111].

Table 1. Peptide-based A $\beta$-, tau-, and $\alpha$-syn vaccines for neurodegenerative diseases: Peptide epitopes and main formulation components used.

\begin{tabular}{|c|c|c|c|c|c|}
\hline Target/Vaccine & Peptide Epitope & $\begin{array}{c}\text { Carrier } \\
\text { Protein/Delivery } \\
\text { System }\end{array}$ & Adjuvant & Type of Study & Reference \\
\hline A $\beta /$ AN1792 & $A \beta(1-42)$ & $\begin{array}{l}\text { Pre-aggregated } \\
\text { peptide }\end{array}$ & QS-21 & Clinical & {$[3,5,59,61,62]$} \\
\hline $\mathrm{A} \beta / \mathrm{CAD} 106$ & $A \beta(1-6)$ & $Q \beta$-VLPs ${ }^{1}$ & Alum or MF59 & Clinical & {$[1,3-5,14,61-64]$} \\
\hline $\mathrm{A} \beta / \mathrm{ACC}-001$ & $\mathrm{~A} \beta(1-7)$ & $\mathrm{CRM}_{197^{2}}$ & QS-21 & Clinical & {$[1,3,5,14,61,62,65]$} \\
\hline $\mathrm{A} \beta / \mathrm{Lu}$ AF20513 & $\mathrm{A} \beta(1-12)$ & Tetanus toxoid & - & Clinical & {$[3-5,61,62]$} \\
\hline $\mathrm{A} \beta / \mathrm{UB}-311$ & $\mathrm{~A} \beta(1-14)$ & UBITh $^{3}$ & Alum $+\mathrm{CpG}^{4}$ & Clinical & {$[3-5,14,61,62,66]$} \\
\hline $\mathrm{A} \beta / \mathrm{ACI}-24$ & $A \beta(1-15)$ & Liposomes & MLPA $^{5}$ & Clinical & {$[1,3,5,14,61,62]$} \\
\hline $\mathrm{A} \beta / \mathrm{V} 950$ & $\mathrm{~A} \beta(1-15)$ & ISCOMATRIX & Quil A & Clinical & {$[3,61,62,66]$} \\
\hline $\mathrm{A} \beta / \mathrm{ABvac} 40$ & $A \beta(33-40)$ & $\mathrm{KLH}^{6}$ & Alum & Clinical & {$[1,3-5,14,61,67]$} \\
\hline $\begin{array}{c}\mathrm{A} \beta / \mathrm{AFFITOPE} \\
\text { AD01 }\end{array}$ & $\begin{array}{l}\mathrm{A} \beta \mathrm{N} \text {-terminus } \\
\text { mimotope }\end{array}$ & KLH & Alum & Clinical & [3] \\
\hline $\begin{array}{c}\mathrm{A} \beta / \mathrm{AFFITOPE} \\
\text { AD02 }\end{array}$ & $\begin{array}{l}\mathrm{A} \beta \mathrm{N} \text {-terminus } \\
\text { mimotope }\end{array}$ & KLH & Alum & Clinical & {$[3,5,14,61,62,69]$} \\
\hline $\begin{array}{c}\mathrm{A} \beta / \text { AFFITOPE } \\
\text { AD03 }\end{array}$ & $\begin{array}{c}\mathrm{A} \beta \mathrm{N} \text {-terminus } \\
\text { mimotope }\end{array}$ & KLH & Alum & Clinical & {$[3,62]$} \\
\hline Tau/AADvac1 & Tau(294-305) & KLH & Alum & Clinical & {$[1,3,4,14,61,85-88]$} \\
\hline Tau/ACI-35 & $\begin{array}{c}\operatorname{Tau}(393-408) \\
{\left[p^{7} 396 / p 404\right]}\end{array}$ & Liposomes & MLPA & Clinical & {$[1,3,4,14,86,88]$} \\
\hline $\begin{array}{c}\alpha-S y n / A F F I T O P E \\
\text { PD01A }\end{array}$ & $\begin{array}{l}\alpha \text {-syn C-terminus } \\
\text { mimotope }\end{array}$ & KLH & Alum & Clinical & {$[14,46,104-107]$} \\
\hline
\end{tabular}


Table 1. Cont.

\begin{tabular}{|c|c|c|c|c|c|}
\hline Target/Vaccine & Peptide Epitope & $\begin{array}{c}\text { Carrier } \\
\text { Protein/Delivery } \\
\text { System }\end{array}$ & Adjuvant & Type of Study & Reference \\
\hline $\begin{array}{c}\alpha-S y n / \\
\text { AFFITOPE PD03A }\end{array}$ & $\begin{array}{l}\alpha \text {-syn C-terminus } \\
\text { mimotope }\end{array}$ & KLH & Alum & Clinical & {$[14,46,104-106]$} \\
\hline $\mathrm{A} \beta$ & $A \beta(1-6)$ & $\begin{array}{l}\text { BLPs }^{8} \text { fused with } \\
\text { peptidoglycan } \\
\text { anchoring domain } \\
\text { (PA) }\end{array}$ & - & Preclinical & [74] \\
\hline$A \beta$ & $\mathrm{A} \beta(1-6)$ & $\begin{array}{c}\text { Norovirus P } \\
\text { Particles }\end{array}$ & $\mathrm{CpG}^{5}$ & Preclinical & [73] \\
\hline $\mathrm{A} \beta$ & $A \beta(3-10)$ & KLH & CFA/IFA & Preclinical & [70-72] \\
\hline$A \beta$ & $\mathrm{A} \beta(1-11)$ & $\begin{array}{l}\text { Bacterial protein } \\
\text { domain E2 }\end{array}$ & Alum & Preclinical & [80] \\
\hline $\begin{array}{l}\text { A } \beta / A V-1959 D \\
\text { DNA vaccine }\end{array}$ & $\mathrm{A} \beta(1-11)$ & MultiTEP $^{9}$ & - & Preclinical & [79] \\
\hline $\mathrm{A} \beta / \mathrm{Y}-5 \mathrm{~A} 15$ & $A \beta(1-15)$ & Yeast cells (EBY-100) & & Preclinical & [77] \\
\hline$A \beta$ & $\mathrm{A} \beta(1-15)$ & Silkworm pupae & $\begin{array}{l}\text { Cholera toxin } \\
\text { B subunit }\end{array}$ & Preclinical & [76] \\
\hline$A \beta$ & $A \beta(1-6), A \beta(1-15)$ & $\begin{array}{l}\text { Multiple antigenic } \\
\text { peptide system }\end{array}$ & CFA/IFA ${ }^{10}$ & Preclinical & [75] \\
\hline$A \beta$ & $\begin{array}{c}\text { cyclo[A } \beta(22-28)-Y^{11} \\
\text { NGK'] } \\
\text { cyclo[A } \beta(23-29)- \\
\text { YNGK'], } \\
\text { cyclo[A } \beta(22-29)- \\
\text { YNGK'] }\end{array}$ & Tetanus toxoid & Alum+MLPA & Preclinical & [81] \\
\hline $\mathrm{A} \beta / \mathrm{AOE} 1$ & $\begin{array}{c}\text { Oligomer-specific } \\
\text { A } \beta \text { mimotope } \\
\text { peptide }\end{array}$ & Yeast cell (EBY-100) & - & Preclinical & [84] \\
\hline $\mathrm{A} \beta$ & $\mathrm{A} \beta(1-42)$ & & CFA+bvPLA2 ${ }^{12}$ & Preclinical & [82] \\
\hline $\begin{array}{c}\mathrm{A} \beta / \\
\text { DNA vaccine }\end{array}$ & $\mathrm{A} \beta(1-42)$ & Gold particles & - & Preclinical & [83] \\
\hline $\mathrm{A} \beta$, Tau & $\mathrm{A} \beta(1-11), \operatorname{Tau}(2-18)$ & MultiTEP & Advax ${ }^{13}+\mathrm{CpG}$ & Preclinical & [78] \\
\hline $\mathrm{A} \beta$, Tau & $\begin{array}{c}\text { Linear } A \beta(1-6), \\
\mathrm{A} \beta(1-6)_{3}, \mathrm{~A} \beta(1-15) \\
\operatorname{Tau}(294-305), \mathrm{p}^{7} \\
\operatorname{Tau}(396-404) \\
\text { pTau422 } \\
\text { cycloA } \beta(1-7) \\
\text { cycloEP1 } 14 \\
\text { cycloEP2 } 14\end{array}$ & $\begin{array}{c}\text { HBc-VLPs } \\
\text { conjugated with } \\
\text { peptides via } \\
\text { SpyCatcher/SpyTag } \\
\text { technology } 15\end{array}$ & Alum & Preclinical & [40] \\
\hline Tau & $\operatorname{Tau}(2-18)$ & MultiTEP & Advax+CpG & Preclinical & {$[34,92]$} \\
\hline Tau & Tau(294-305) & HBc-VLPs 16 & Alum & Preclinical & [94] \\
\hline Tau & $\operatorname{Tau}(175-190)[\mathrm{p} 181]$ & $\mathrm{Q} \beta-V L P S$ & & Preclinical & [96] \\
\hline Tau & $\begin{array}{c}\operatorname{Tau}(195-213) \\
{[\mathrm{p} 202 / 205],} \\
\operatorname{Tau}(207-220) \\
{[\mathrm{p} 212 / 214]} \\
\operatorname{Tau}(224-238)[\mathrm{p} 231]\end{array}$ & - & $\begin{array}{c}\text { CFA+pertussis } \\
\text { toxin }\end{array}$ & Preclinical & [95] \\
\hline
\end{tabular}


Table 1. Cont.

\begin{tabular}{|c|c|c|c|c|c|}
\hline Target/Vaccine & Peptide Epitope & $\begin{array}{c}\text { Carrier } \\
\text { Protein/Delivery } \\
\text { System } \\
\end{array}$ & Adjuvant & Type of Study & Reference \\
\hline Tau & $\begin{array}{l}\text { Tau(379-408) } \\
\text { [p396/404] }\end{array}$ & & Alum & Preclinical & [100] \\
\hline Tau & $\begin{array}{c}\text { pTau30 } \\
\text { [p202/205/238/262], } \\
\text { pTau31 } \\
\text { [p202/205/396/404] } \\
\text { pTau35 } \\
\text { [p238/262/396/404] }\end{array}$ & $\begin{array}{c}\text { Norovirus P } \\
\text { particles }\end{array}$ & $\mathrm{CpG}+\mathrm{AS} 01$ & Preclinical & [97] \\
\hline$\alpha$-Syn & $\begin{array}{c}\alpha-\operatorname{Syn}(85-99) \\
\alpha-\operatorname{Syn}(109-126) \\
\alpha-\operatorname{Syn}(126-140)\end{array}$ & Tetanus toxoid & Quil A & Preclinical & [111] \\
\hline$\alpha$-Syn & $\begin{array}{c}\text { middle region: } \mathrm{C}^{11} \\
\text { GGKNEEGAPQ } \\
\text { (PD1) } \\
\text { N-terminal: } \\
\text { MDVFMKGLGGC } \\
\text { (PD2) } \\
\text { C-terminal: } \\
\text { CGGEGYQDYEPEA } \\
\text { (PD3) }\end{array}$ & $\mathrm{Q} \beta$-VLPs & - & Preclinical & [43] \\
\hline
\end{tabular}

${ }^{1} \mathrm{Q} \beta$-VLP: Virus-like particles from capsid proteins of $Q \beta$ bacteriophage. ${ }^{2}$ CRM197: Nontoxic mutant of diphtheria toxin. ${ }^{3}$ UBITh: Two different helper T cell peptide epitopes, MvF5 Th and HBsAg3 Th. ${ }^{4}$ CpG: Cytosine phosphoguanosine motif. ${ }^{5}$ MLPA: Monophosphoryl lipid A. ${ }^{6}$ KLH: Keyhole limpet hemocyanin. ${ }^{7}$ p: Phosphorylated amino acid residue(s) at a specific site in the protein sequence. ${ }^{8}$ BLPs: Bacterium-like particles. ${ }^{9}$ MultiTEP: A platform composed of 12 foreign helper T (Th) cell epitopes. ${ }^{10}$ CFA/IFA: Complete Freund's Adjuvant/Incomplete Freund's Adjuvant. ${ }^{11}$ Amino acids shown with the one-letter code. ${ }^{12}$ bvPLA2: Bee venom phospholipase A2. 13 Advax: A novel polysaccharide-based adjuvant derived from crystalline particles of delta inulin, a natural plant sugar comprised of fructose and glucose units. ${ }^{14}$ EP1, EP2: Special peptide epitopes of A $\beta$ oligomers selected with phage display from random peptide libraries. ${ }^{15}$ SpyCatcher/SpyTag technology: A novel method to load particulate epitopes on virus-like particles through the formation of an iso-peptide bond between the SpyCatcher protein and SpyTag peptide. ${ }^{16} \mathrm{HBC}$ VLP: Virus-like particles from hepatitis B virus core protein.

\section{Formulation Components of Peptide-Based Vaccines for Neurodegenerative Diseases}

Although the major challenge in peptide-vaccine development is the epitope selection, the wrong formulation may render a particular vaccine insufficient. The inclusion of suitable formulation components is necessary for optimal efficacy since peptides usually elicit a weak immune response by themselves, are especially prone to enzymatic degradation, while they are unlikely to stay deposited at the administration site thus allowing interaction with the immune cells recruited on the spot. Moreover, peptide-vaccines are usually based on B-cell epitopes and the T-cell epitopes necessary for a strong immune response are usually provided by a suitable carrier protein (see Section 4.1) or through particular delivery systems (see Section 4.2), the latter being mainly defined as the technology to administer or transport vaccine components. Adjuvants (see Section 4.3), on the other hand, which are defined mainly as agents capable of enhancing the immune response, are often formulated as a part of the vaccine [54].

Focusing on peptide-based vaccines for neurodegenerative diseases, the results of the first $\mathrm{AD}$ vaccine entered clinical trials, AN1792, along with the nature of these diseases have paved the way for developing/selecting better formulation components. More specifically, the phase II clinical trial of AN1792 was terminated due to meningoencephalitis; this side-effect has been attributed to detrimental proinflammatory Th1 autoimmune response induced not only by $\mathrm{T}$ cell epitopes from $\mathrm{A} \beta(1-42)$, but also by QS-21 adjuvant (Section 4.3.3), a potent Th1 immune stimulator, and maybe by the detergent polysorbate 80 added to the vaccine formulation [61,112]. Another problem of the clinical trials with AN1792 
was modest immunogenicity, with only a small number of subjects showing adequate anti-A $\beta$ antibody titer, which might have affected the therapeutic effect. On the other hand, immunosenescence, i.e., the deterioration of the immune system linked to aging, is a major challenge to the development of vaccines for the elderly population and this should be considered along with poor peptide immunogenicity when designing a peptidebased vaccine against neurodegeneration [112]. Thus, the "next-generation" vaccines for degenerative diseases were based on B-cell peptide epitopes of the target molecule and used carrier proteins/delivery systems/adjuvants which would ideally switch to Th2 immune responses.

\subsection{Carrier Proteins}

Keyhole limpet hemocyanin (KLH) is a large protein of the organism Megathura crenulata carrying $\mathrm{T}$ cell epitopes, which has been widely used as a carrier protein stimulating mainly a Th2 response [14]. KLH has been used in several peptide-based vaccines for neurodegenerative diseases (Table 1). Thus, the ABvac40 vaccine is based on $A \beta(33-40)$ conjugated to KLH [67]. AFFITOPE AD01, AD02, and AD03 are conjugated to KLH peptide vaccines $[3,62,69]$. The AADvac1 tau-vaccine consists of a cysteinylated 12-mer tau peptide (Tau294-305) conjugated to KLH [85-88]. PD vaccine candidates (AFFITOPE PD01A and PD03A) contain appropriate peptide epitopes conjugated to KLH [106,107]. Moreover, the $\mathrm{A} \beta(3-10)-\mathrm{KLH}$ conjugate has been used for animal vaccination in recent preclinical studies [70-72].

The so-called cross-reacting material 197 (CRM197) carrier protein is an inactivated and non-toxic form of diphtheria toxin. CRM197 can rapidly activate CD4+ T cells by generating a multitude of Th1 and Th2 cytokines, thereby promoting the proliferation of $\mathrm{B}$ cells and regulating the level of antibody production [113]. In a phase II clinical trial of the AD vaccine ACC-001, multiple copies of $A \beta(1-7)$ peptide conjugated to CRM197 were used [65].

Tetanus toxoid (TT) is used as a carrier protein possessing multiple CD4+ T-cell (Th) epitopes. In LuAF20513 vaccine, $A \beta(1-12)$ was conjugated to two foreign Th epitopes from TT, P2, and P30, and experimental data in transgenic mice as well as in guinea pigs and cynomolgus monkeys showed that the vaccine improved the ability to elicit an effective immune response by stimulating preexisting memory Th cells, which would eventually prove to be a great advantage in vaccination of the elderly [61,114]. Moreover, in a recent preclinical study, a vaccine based on small cyclic peptides of $A \beta$ that had been conjugated to TT could improve memory deficits in J20 mice [81]. In a previous study, a PD vaccine including three peptides of $\alpha$-syn that had also been conjugated to TT was reported [111].

The UB-311 vaccine was based on two $\mathrm{A} \beta(1-14)$ peptides, each linked to different helper T-cell peptide epitopes (UBITh) derived from the highly immunogenic measles virus fusion protein (MvF5) and hepatitis B virus surface antigen (HBsAg3). The peptides have been mixed with polyanionic CpG oligodeoxynucleotides (Section 4.3.4), so as to form stable micrometer-sized particulates. This strategy seems to bias Th2 over Th1 type responses [66].

The multimeric protein (1-11)E2 is a fusion protein including the first $11 \mathrm{~N}$-terminal residues of $A \beta$ and the bacterial protein domain E2, which self-assembles into a 60-mer complex; (1-11)E2 has been used for vaccinating transgenic mice in a recent preclinical study [80].

The so-called multiple antigen peptides (MAPs), i.e., synthetic peptide dendrimers which contain two functional structures, a branched oligo-lysine core, and multiple copies of peptide epitopes (often, B- and T- cell ones), have been used as immunogens instead of the conventional peptide/carrier protein conjugates. In a recent study, a four-branched MAP $\left[(\mathrm{MAP})_{4}\right]$ was covalently coupled with $\mathrm{A} \beta$ linear epitopes, i.e., $\mathrm{A} \beta(1-6)$ or $\mathrm{A} \beta(1-15)$, via 6-aminohexanoic acid to enhance epitope flexibility, and the products were used for animal immunization with promising results [75]. 


\subsection{Delivery Systems}

\subsubsection{Virus-like, Bacterium-like, and Inorganic Particles}

Virus-like particles (VLPs) are self-assembly systems that spontaneously form virusshaped particles. VLPs cannot replicate due to the lack of viral genetic material, thus being biosafe. Due to their size, they can efficiently enter lymphatic vessels and reach lymph nodes. VLPs efficiently induce B-cell responses due to high-epitope density on their surface, and also T-cell responses through interactions with antigen-presenting cells (APCs). Hepatitis B virus core protein ( $\mathrm{HBc}$ ), especially the major immunodominant region (MIR) of truncated HBc, can be assembled into VLPs and has been used for the insertion of foreign epitopes. In a recent study, HBc VLPs were used as carriers of a series of $A \beta$ and tau epitopes. More specifically, a platform for peptide vaccine preparation was first constructed by inserting the so-called SpyCatcher protein into MIR. The resulting recombinant protein, HBc-SpyCatcher, could self-assemble in VLPs and readily bind to the epitope peptides that had been conjugated to the so-called SpyTag, of peptide nature, through a glutamic acid-glutamic acid (EE)/glycine-serine-glycine (GSG) linker. The final products were used for animal immunization with promising results [40]. Previously, tau(294-305) was fused to MIR and the VLPs formed were used for animal immunization with good preliminary results, both biochemical/histochemical and functional [94]. Another VLP system is based on $Q \beta$ bacteriophage. CAD106 vaccine combines multiple copies of $A \beta(1-6)$ coupled to a $Q \beta$ VLP [64]. Q $\beta$ VLP-based vaccines which used either tau(175-190), phosphorylated at $\mathrm{Thr}^{181}$ [96], or peptides from the N-terminal, middle and C-terminal region of $\alpha$-syn [43] were also developed and tested in animals.

Norovirus P particles (NoV P) have been used as a carrier/delivery system of $A \beta$ and tau peptides $[73,97]$ in animal studies, in which high titer-specific antibodies were elicited, with no parallel autoimmune T-cell activation.

Bacterium-like particles (BLPs) can also serve as multifunctional and safe carrier/delivery systems. BLPs have the same shape and size as the living bacterium, but they consist of peptidoglycan shell particles without the intracellular content of Lactococcus lactis bacteria. Peptide epitopes can be specifically loaded on the surface of BLPs via fusion with a peptidoglycan anchoring domain (PA). Different copy numbers of $A \beta(1-6)$ were fused to PA, loaded to the surface of BLPs and the BLP-based vaccines were tested in mice [74].

Gold particles were employed as a delivery system, at least according to the authors' previous publications [115], in a DNA vaccine based on $A \beta(1-42)$ trimer, which was tested in transgenic mice [83].

\subsubsection{Liposomes and Miscellaneous Other Systems}

Liposomes have been widely used for peptide-vaccine delivery since they protect peptide epitopes from enzymatic degradation and can enhance antigen presentation. The ACI-24 vaccine uses $A \beta(1-15)$ peptides anchored to the surface of a liposome as a delivery system [14,61]. ACI-35 is a liposome-based tau-vaccine candidate that contains 16 copies of a synthetic tau phospho-peptide; peptides have been suitably modified, so as to include two palmitic acid chains at each terminus and thus allow assembly into liposomes $[14,88]$.

In the V950 vaccine, the $\mathrm{A} \beta \mathrm{N}$-terminus was chemically linked directly to ISCOMATRIX, which is a delivery system made up of cholesterol, phospholipids, and saponins as an adjuvant, probably through a lipid anchor [68].

The yeast cell is a promising vaccine carrier and adjuvant. Yeast cells can express heterologous proteins/peptides using a surface display system; the epitopes displayed on the cell surface can be efficiently recognized by antigen-presenting cells. A yeast-based $A \beta$ vaccine (Y-5A15) composed of five copies of $A \beta(1-15)$ that had been displayed on the surface of a yeast cell's wall was tested in transgenic mice [77]. Another yeast-based A $\beta$ vaccine (AOE1), in which $A \beta$ oligomer-specific mimotope peptides had been displayed on the yeast cell surface, was tested in specific mouse models [84].

In recent animal preclinical studies, two MultiTEP epitope vaccines, AV-1959R and AV-1980R, targeting A $\beta(1-11)$ and tau(2-18), respectively, were developed as a combined 
vaccination approach targeting both $A \beta$ and tau pathologies [78]; MultiTEP-using vaccines targeting separately tau [34] or $A \beta[79]$ have been also developed and administered to animals. The MultiTEP platform was composed of 12 foreign Th cell epitopes, including a wide array of tetanus toxin, hepatitis B, and influenza Th epitopes. In this way (i.e., by activating, besides naïve Th cells, the pre-existing memory Th cells previously generated in response to infections and/or vaccinations with tetanus toxin, hepatitis B, and influenza), a unique opportunity to overcome immunosenescence in the elderly might be eventually provided.

\subsection{Adjuvants}

Some of the characteristics that adjuvants should have to be approved for clinical use are to be non-toxic and capable of effectively stimulating humoral and cellular immune responses with no adverse reactions, induce no autoimmune or allergic responses, and elicit long-lasting immunity. In most cases, the transition from an adjuvant that is effective in animals to human trials is challenging [116]. Currently, very few adjuvants are used in FDA-approved vaccines and these include alum (see Section 4.3.1), MF59 (see Section 4.3.2), CpG ODN (see Section 4.3.4) as well as AS01, AS03, and AS04, while many others are under experimental or clinical investigation [117].

\subsubsection{Alum Adjuvants}

Aluminum salts are the most extensively used adjuvants in vaccine formulations approved by the FDA. The types of aluminum salts, often referred to as alum, include aluminum hydroxide, aluminum phosphate, and amorphous aluminum hydroxyphosphate sulfate. Alum is known as a strong Th2 immune stimulator, and several mechanisms have been proposed to explain its stimulatory activity $[117,118]$. Although it is generally considered quite a good human vaccine excipient, alum has shown poor immune-stimulating activity when administered with peptide-based vaccines; a possible explanation is that alum cannot efficiently protect peptides from proteolytic degradation [119].

Despite the aforementioned controversial opinions on its efficiency, alum is currently widely used in peptide-based vaccines for neurodegenerative diseases, alone or in combination with other excipients, both at the clinical and preclinical level. Concerning clinical trials, alum has been used in the formulation of AD and PD vaccines. More specifically, in phase II clinical trials of CAD106, alum (or MF59, Section 4.3.2) was mixed with reconstituted active CAD106, and the combined product induced optimal titers of A $\beta$-specific antibodies, with well-acceptable tolerability [64]. UB-311 vaccine was also formulated in an alum-containing Th2-biased delivery system, in combination with CpG ODN adjuvant (Section 4.3.4) [66]. In clinical trials of AFFITOPE AD02 and AD03 vaccines, aluminum hydroxide was added as an adjuvant showing a good safety profile [62,69]. Interestingly, in a phase II trial of AFFITOPE AD02, patients showed greater benefits for the placebo formulation AD04, containing only the adjuvant [69]. Finally, in two other AD vaccines, ABvac40 and AADvac1, and two PD vaccines, AFFITOPES PD01A and PD03A, alum was added as adjuvant $[67,85,106,107]$. On the other hand, in a few AD vaccines preclinically tested in animals lately, alum was added as an adjuvant, either alone $[40,80,94,100]$ or in combination with monophosphoryl lipid A [81].

\subsubsection{Emulsion Adjuvants}

There are two types of emulsions used in vaccine formulation, oil-in-water, and waterin-oil. In these systems, immunogens are adsorbed onto the emulsion droplets, are slowly released from the depot at the injection site, and up-taken by recruited immune cells. Freund's adjuvant leads to water-in-oil emulsions and is widely used in animal vaccine research, while it is not approved for human use. Complete Freund's adjuvant (CFA), which is usually necessary for prime immunization and induces a Th1-dominated response, consists of heat-killed Mycobacterium tuberculosis in non-metabolizable oils (paraffin oil and mannide monooleate), while Incomplete Freund's Adjuvant (IFA), which is usually 
employed in booster immunizations and induces a Th2-biased response, is the same with CFA but it does not contain mycobacteria. Usage of CFA in vaccine formulation has been associated with undesirable side effects, such as weight loss, leucocytosis, and granulomatous peritonitis in mice [118,120]. Nevertheless, CFA has been used in the formulation of candidate $\mathrm{AD}$ vaccines tested in animal preclinical studies, often in combination with IFA $[70-72,75,82]$ or in combination with Bordetella pertussis toxin (PT), in order to induce a proinflammatory CNS milieu resembling disease background [95].

MF59, which is composed of squalene, leads to oil-in-water emulsions and is licensed in Europe as the adjuvant component of influenza vaccines. Although MF59 cannot provide a long-lived depot at the injection site, it can induce chemokine secretion and immunogen uptake by monocytes that are subsequently differentiated to dendritic cells [118]. In phase II clinical trials of CAD106, MF59 (or alum, Section 4.3.1) was used as adjuvant [64].

\subsubsection{Saponin Adjuvants}

Saponins are natural glycoside compounds and their ability to activate the human immune system has enabled their use as vaccine adjuvants. QS-21 is a triterpene glycoside of quillaic acid isolated from the bark of the Quillaja saponaria Molina tree. It is typically used in absence of a carrier vehicle and is effective in aqueous solutions. QS-21 can be recognized by lectin receptors on antigen-presenting cells and also induces cytotoxic T-cell activation, Th1 cytokine production (IL-2 and IFN- $\gamma$ ), specific antibody responses, Th1 and Th2 immune responses, and antigen cross-presentation [121]. The first AD vaccine, AN1792, contained QS-21 as an adjuvant, which might have contributed to the development of meningoencephalitis side-effects [59,122]. QS-21 was also used as an adjuvant in ACC-001 vaccine [65]. In addition, in recent animal studies of tau-peptide-based vaccines, QS-21 was added in the form of AS02 adjuvant (QS-21 and monophosphoryl lipid A, oil-in-water emulsion), combined with CpG ODN (Section 4.3.4) [97]. On the other hand, Quil A is a highly purified saponin adjuvant also isolated from bark extract of the Quillaja saponaria Molina tree. It consists of a complex mixture of around 25 different saponin molecules which share a common triterpenoid backbone and induces a balanced Th1/Th2 immune response. Quil A was added as an adjuvant in the formulation of the V950 vaccine in combination with the carrier/delivery system ISCOMATRIX [61] and was also used in animal testing of $\alpha$-syn-peptide vaccines [111].

\subsubsection{Miscellaneous Other Adjuvants}

Cytosine phospho-Guanosine ( $\mathrm{CpG}$ ) motifs in bacterial DNA seem to enhance immune stimulation. The synthetic form of $\mathrm{CpG}$, the $\mathrm{CpG}$ oligodeoxynucleotides (CpG-ODN), is composed of ODNs with a phosphorothioate backbone containing unmethylated CpG motifs. CpG ODN is an agonist of Toll-like receptor 9 (TLR9) and can induce specific humoral and cellular immune responses of mainly Th1-type, which include cytotoxic T-cell generation and IFN- $\gamma$ secretion [117]. CpG ODN was used as an adjuvant in combination with alum in phase I clinical trial of UB-311 vaccine [66]. In animal preclinical studies, CpG has been used as an adjuvant either in combination with Advax [34,78].

Advax is a novel polysaccharide adjuvant based on delta inulin, which successfully enhances the immunogenicity of vaccines, including peptide-based ones, as estimated mainly through specific antibody titers, and $\mathrm{CD} 4^{+} / \mathrm{CD}^{+} \mathrm{T}$-cell immune responses, while it acts synergistically with traditional innate immune activators, such as CpG ODN. Both in preclinical studies and human clinical trials, Advax has shown a very good profile of safety, tolerability, and efficacy [123] and has been used in combination with CpG as an adjuvant in animal preclinical studies of candidate AD vaccines [34,78].

Monophosphoryl lipid A (MPLA) is a highly purified derivative of the lipopolysaccharide (LPS) component of the cell wall of Salmonella enterica. It stimulates $\mathrm{T}$ cell responses and specific antibody generation and could activate innate immunity via Toll-like receptor 4 (TLR4), thus leading to mildly inflammatory conditions which favor the generation of Th1-associated humoral responses $[118,124]$. MLPA was added to the formulation of 
ACI-24 [61] and ACI-35 [88] vaccines as well as in research preclinical studies, combined with QS-21 (as AS02 adjuvant) [97], or alum [81].

The cholera toxin subunit-B (CTB) can be used as a powerful adjuvant to generate mucosal immunity and can enhance oral immune tolerance, due to its strong affinity to the monosialoganglioside (GM1) receptor, which is primarily located on mucosal epithelial cells. Thus, it was included in the formulation components of a vaccine composed of a CTB-A $\beta(1-15)$ fused protein expressed in silkworm pupae, which was subsequently used for oral vaccination of transgenic mice [76].

In a recent pre-clinical study, co-immunization of an $\mathrm{AD}$ mouse model with intact $A \beta(1-42)$ together with bee venom phospholipase A2 (bvPLA2) showed that bvPLA2 induces regulatory T cells (CD4+ CD25+ Foxp3+ T cells, Tregs) and ameliorates AD pathology, without undesirable $\mathrm{T}$ cell-mediated inflammation. These findings suggest that bvPLA2 administration can improve the safety of vaccination with intact $A \beta(1-42)$ [82].

\section{Animal Studies as a Research Tool for the Preclinical Evaluation of the Peptide-Based Vaccines against Neurodegenerative Diseases}

5.1. Animal Models and Immunization Schemes Used in Recent Preclinical Studies

Choosing the right animal model to test the effectiveness of a candidate human vaccine at the preclinical level is of utmost importance. Ideally, the animal model used should closely resemble the disease in humans, sharing the mode of disease onset-progression and the type of immune response elicited after vaccination. To this end, a series of animal models for $\mathrm{AD}$ or other neurodegenerative diseases have been created/selected and used. Focusing on studies recently reported, various transgenic mouse models including APP/PS1 [71,77]/APPswe/PS1dE9 co-expressing human APP with Swedish mutation and exon-9-deleted presenilin [72,76,95], TauP301S of AD and Frontotemporal dementia phenotype $[40,94,97], 3 x T g$-AD involving both $\mathrm{A} \beta$ and p-tau pathology $[70,80,82,83,100]$, $\mathrm{EAE} / \mathrm{AD}$ deriving from APP/PS1 crossed with EAE (experimental autoimmune encephalomyelitis) [84], Tau22/5xFAD developing both pathological $A \beta$ and tau aggregates [78], PS19 [92], J20 [81], SNCA-OVX [43], B6SJL [111], Tg2576 as well as Tg-SwDI [79], and $\operatorname{Tg} 4510[34,96]$ have been employed. On the other hand, a few studies have employed Balb/C or C57/BL6 mice, so as to preliminarily estimate the vaccine capability of eliciting high antibody titers [73-75] (Table 2).

When a new vaccine is tested in research preclinical studies, there is not a general vaccination protocol to follow; thus, the immunization scheme is mainly based on previous experience of the researchers. For this reason, there are several differences regarding the route of administration, the total number of doses administered or the time interval(s) between the "prime" dose and the "booster" one(s) among studies (Table 2). Regarding the route of administration, the majority of studies employed subcutaneous (s.c.) administration, while few others selected the intramuscular (i.m.) route $[34,73,74,78,92,96]$. A few studies used intradermal (i.d.) administration of DNA vaccine formulations $[79,83]$ and one tested oral administration [76]. The total number of doses may also differ (Table 2). The majority of the reported protocols include at least three doses, with 4 to 6 doses usually selected [71-75,78,82,92,94,100,111]. However, as many as 14 doses [43] or an everyday oral administration protocol for a period of almost 9 months [76] have also been reported. 
Table 2. Peptide-based A $\beta$-, tau-, and $\alpha$-syn vaccines for neurodegenerative diseases: Animal models, vaccination schemes and methods for evaluating efficacy reported in recent preclinical studies.

\begin{tabular}{|c|c|c|c|c|c|}
\hline Target & Peptide Epitope & Animal Model & $\begin{array}{l}\text { Vaccination Scheme } \\
\text { (Administration } \\
\text { Route/Doses/Time } \\
\text { Intervals) }\end{array}$ & $\begin{array}{l}\text { Methods for Evaluating } \\
\text { Vaccination Efficacy }\end{array}$ & Reference \\
\hline$A \beta$ & $A \beta(1-6)$ & C57/BL6 mice & $\begin{array}{c}\text { i.m. }{ }^{1 / x} / / 2 \mathrm{w} \\
\text { intervals }\end{array}$ & $\begin{array}{c}\text { In vitro: ELISA; ELISpot; } \\
\text { MTT }^{2} \text { assay }\end{array}$ & {$[74]$} \\
\hline$A \beta$ & $\mathrm{A} \beta(1-6)$ & C57/BL6 mice & $\begin{array}{l}\text { i.m. } / \mathrm{x} 4 / 2 \mathrm{w} \\
\text { intervals }\end{array}$ & In vitro: ELISA; ELISpot & [73] \\
\hline $\mathrm{A} \beta$ & $\mathrm{A} \beta(3-10)$ & $\begin{array}{l}\text { APPSwe/PSEN1dE9- } \\
\text { mice }\end{array}$ & $\begin{array}{c}\text { s.c. }{ }^{1 / x} 6 / \\
2 \mathrm{w} \text { intervals }\end{array}$ & $\begin{array}{l}\text { In vitro: ELISA; } \\
\text { immunohistochemistry; } \\
\text { Western Blot; TUNEL }^{3} \\
\text { staining; ROS }{ }^{4} \text { staining }\end{array}$ & [72] \\
\hline $\mathrm{A} \beta$ & $\mathrm{A} \beta(3-10)$ & 3xTg-AD mice & $\begin{array}{l}\text { s.c. } / \mathrm{x} 7 / 2 \mathrm{w} \text { or } 4 \mathrm{w} \\
\text { intervals }\end{array}$ & $\begin{array}{c}\text { In vitro: ELISA; } \\
\text { immunohistochemistry; } \\
\text { Western Blot } \\
\text { In vivo: MWM test }\end{array}$ & [70] \\
\hline $\mathrm{A} \beta$ & $\mathrm{A} \beta(3-10)$ & APP/PS1 mice & $\begin{array}{c}\text { s.c. } / x 5 / \\
2 \mathrm{w} \text { or } 4 \mathrm{w} \text { inter-vals }\end{array}$ & $\begin{array}{l}\text { In vitro: ELISA; } \\
\text { immunohistochemistry } \\
\text { In vivo: MWM test }\end{array}$ & [71] \\
\hline$A \beta$ & $\mathrm{A} \beta(1-11)$ & 3xTg-AD mice & $\begin{array}{l}\text { s.c. } / \mathrm{x} 3 / 4 \mathrm{~m} \text { or } 5 \mathrm{~m} \\
\text { intervals }\end{array}$ & $\begin{array}{c}\text { In vitro: ELISA; } \\
\text { immunohistochemistry; } \\
\text { Thioflavin S staining }\end{array}$ & [80] \\
\hline $\mathrm{A} \beta$ & $\begin{array}{c}\text { A } \beta(1-11) \\
\text { DNA vaccine }\end{array}$ & $\begin{array}{l}\text { Tg2576 mice } \\
\text { Tg-SwDI mice }\end{array}$ & $\begin{array}{c}\text { i.d. }{ }^{1 / x} 4 / \\
2 \mathrm{w} \text { or } 4 \mathrm{w} \text { intervals }\end{array}$ & $\begin{array}{c}\text { In vitro: ELISA; } \\
\text { immunohistochemistry } \\
\text { In vivo: MRI }{ }^{5} \text { imaging }\end{array}$ & [79] \\
\hline$A \beta$ & $\mathrm{A} \beta(1-15)$ & $\mathrm{APP} / \mathrm{PS} 1$ mice & $\begin{array}{c}\text { s.c. } / \mathrm{x} 3 / \\
2 \mathrm{w} \text { intervals }\end{array}$ & $\begin{array}{c}\text { In vitro: ELISA; } \\
\text { immunohistochemistry; } \\
\text { Western Blot } \\
\text { In vivo: Spontaneous Y } \\
\text { maze test; NOR }{ }^{6} \text { test; } \\
\text { MWM }^{7} \text { test }\end{array}$ & [77] \\
\hline $\mathrm{A} \beta$ & $A \beta(1-15)$ & $\begin{array}{l}\text { APPSwe/PSEN1dE9- } \\
\text { mice }\end{array}$ & $\begin{array}{l}\text { Orally/every day for } \\
\sim 9 \text { months }\end{array}$ & $\begin{array}{c}\text { In vitro: ELISA; } \\
\text { Immunohistochemistry } \\
\text { In vivo: water maze test }\end{array}$ & [76] \\
\hline$A \beta$ & $A \beta(1-6), A \beta(1-15)$ & Balb/C mice & s.c. $/ x 4 / 2 \mathrm{w}$ intervals & $\begin{array}{c}\text { In vitro: ELISA; Dot Blot; } \\
\text { Thioflavin T staining; } \\
\text { TEM }^{8} \text { scanning }\end{array}$ & [75] \\
\hline$A \beta$ & $\begin{array}{c}\text { cyclo[A } \beta(22-28)-\mathrm{Y}^{9} \\
\text { NGK'], } \\
\text { cyclo[A } \beta(23-29)- \\
\text { YNGK'], } \\
\text { cyclo[A } \beta(22-29)- \\
\text { YNGK'] }\end{array}$ & $\mathrm{J} 20$ & s.c. $/ x 3 / 1 \mathrm{~m}$ intervals & $\begin{array}{c}\text { In vitro: ELISA; } \\
\text { immunohistochemistry } \\
\text { In vivo: OF }{ }^{10} \text { test; SA }{ }^{11} \\
\text { test; NOR test; NLR }{ }^{12} \\
\text { test; MWM test }\end{array}$ & [81] \\
\hline$A \beta$ & $\begin{array}{l}\text { Oligomer-specific } \\
\text { A } \beta \text { mimotope } \\
\text { peptide }\end{array}$ & $\mathrm{EAE} / \mathrm{AD}$ mice & s.c. $/ \times 5 / 2 \mathrm{w}$ intervals & $\begin{array}{c}\text { In vitro: ELISA; } \\
\text { Immunohistochemistry } \\
\text { In vivo: MWM test; Y } \\
\text { maze test; NOR test }\end{array}$ & [84] \\
\hline$A \beta$ & $\mathrm{A} \beta(1-42)$ & $\begin{array}{c}\text { 3xTg-AD mice } \\
\text { or } \\
\text { Neuroinflammation } \\
\text { model in C57/BL6 }\end{array}$ & s.c. $/ \times 6 / 2 \mathrm{w}$ intervals & $\begin{array}{c}\text { In vitro: ELISA; } \\
\text { immunohistochemistry; } \\
\text { Flow cytometry } \\
\text { In vivo: MWM test; PET } \\
13 \text { scanning }\end{array}$ & [82] \\
\hline
\end{tabular}


Table 2. Cont.

\begin{tabular}{|c|c|c|c|c|c|}
\hline Target & Peptide Epitope & Animal Model & $\begin{array}{c}\text { Vaccination Scheme } \\
\text { (Administration } \\
\text { Route/Doses/Time } \\
\text { Intervals) }\end{array}$ & $\begin{array}{l}\text { Methods for Evaluating } \\
\text { Vaccination Efficacy }\end{array}$ & Reference \\
\hline $\mathrm{A} \beta$ & $\begin{array}{c}\text { A } \beta(1-42) \\
\text { DNA vaccine }\end{array}$ & 3xTg-AD mice & $\begin{array}{c}\text { i.d./x13/ } \\
2 \mathrm{w} \text { or } 6 \mathrm{w} \text { intervals }\end{array}$ & $\begin{array}{l}\text { In vitro: ELISA; ELISpot; } \\
\text { immunohistochemistry; } \\
\text { Western Blot }\end{array}$ & [83] \\
\hline $\mathrm{A} \beta$, Tau & $\mathrm{A} \beta(1-11), \operatorname{Tau}(2-18)$ & $\begin{array}{c}\text { Tau22/5xFAD } \\
\text { bigenic mice (T5x) }\end{array}$ & $\begin{array}{l}\text { i.m. } / \mathrm{x} 4 / 1 \mathrm{~m} \text { or } 1.5 \mathrm{~m} \\
\text { intervals }\end{array}$ & $\begin{array}{c}\text { In vitro: ELISA; } \\
\text { immunohistochemistry; } \\
\text { Western Blot; SPR }{ }^{14} \\
\text { biosensor }\end{array}$ & [78] \\
\hline $\mathrm{A} \beta, \mathrm{Tau}$ & $\begin{array}{c}\text { Linear A } \beta(1-6), \\
\text { A } \beta(1-6)_{3}, A \beta(1-15), \\
\text { Tau(294-305), p }{ }^{15} \\
\text { Tau(396-404), } \\
\text { pTau422 } \\
\text { cycloA } \beta(1-7), \\
\text { cycloEP1 16, } \\
\text { cycloEP2 16 }\end{array}$ & $\begin{array}{l}\text { BALB } / \mathrm{c} \text { mice } \\
\text { and } \\
\text { TauP301S mice }\end{array}$ & $\begin{array}{l}\text { s.c. } 3 \text { times at } 2 \mathrm{w} \\
\text { intervals } \\
\text { s.c. } 4 \text { times at } 2 \mathrm{w} \\
\text { intervals }\end{array}$ & $\begin{array}{c}\text { In vitro: ELISA; } \\
\text { immunohistochemistry } \\
\text { In vivo: Forced Y maze } \\
\text { test; NOR test; MWM } \\
\text { test }\end{array}$ & [40] \\
\hline Tau & $\operatorname{Tau}(2-18)$ & $\operatorname{Tg} 4510$ mice & $\begin{array}{c}\text { i.m. } / x 7 / 2 \mathrm{w} \text { or } 4 \mathrm{w} \\
\text { intervals }\end{array}$ & $\begin{array}{l}\text { In vitro: ELISA; ELISpot; } \\
\text { immunohistochemistry; } \\
\text { Western blot } \\
\text { In vivo: NOR test; } \\
\text { RAWM }{ }^{17} \text { test }\end{array}$ & [34] \\
\hline Tau & $\operatorname{Tau}(2-18)$ & PS19 mice & $\begin{array}{l}\text { i.m. } / \mathrm{x} 4 \text { times } / 1 \mathrm{~m}, \\
1.5 \mathrm{~m} \text {, or } 2.5 \mathrm{~m} \\
\text { intervals }\end{array}$ & $\begin{array}{c}\text { In vitro: ELISA; } \\
\text { immunohistochemistry; } \\
\text { Western blot, Dot Blot, } \\
\text { confocal microscopy } \\
\text { In vivo: Rotarod test; } \\
\text { Y-maze test; NOR test; } \\
\text { NPR }{ }^{18} \text { test }\end{array}$ & [92] \\
\hline Tau & $\operatorname{Tau}(294-305)$ & TauP301S mice & $\begin{array}{l}\text { s.c. } / \mathrm{x} 4 / 2 \mathrm{w} \text { or } 3 \mathrm{w} \\
\text { intervals }\end{array}$ & $\begin{array}{c}\text { In vitro: ELISA; } \\
\text { immunohistochemistry; } \\
\text { Western blot } \\
\text { In vivo: Forced Y maze } \\
\text { test; Spontaneous Y } \\
\text { maze test; NOR test; } \\
\text { MWM test }\end{array}$ & [94] \\
\hline Tau & $\operatorname{Tau}(175-190)[\mathrm{p} 181]$ & $\operatorname{Tg} 4510$ mice & $\begin{array}{l}\text { i.m. } / \mathrm{x} 3 \text { times } / 2 \mathrm{w} \\
\text { intervals }\end{array}$ & $\begin{array}{l}\text { In vitro: ELISA; } \\
\text { immunohistochemistry; } \\
\text { Western blot } \\
\text { In vivo: NOR test; } \\
\text { MWM test }\end{array}$ & [96] \\
\hline Tau & $\begin{array}{c}\operatorname{Tau}(195-213)[\mathrm{p} \\
\text { 15202/205]; } \\
\operatorname{Tau}(207-220) \\
\text { [p212/214]; } \\
\operatorname{Tau}(224-238)[\mathrm{p} 231]\end{array}$ & $\begin{array}{l}\text { APPSwe/PSEN1dE9 } \\
\text { mice }\end{array}$ & s.c. $/ \times 2 / 1 \mathrm{w}$ interval & $\begin{array}{c}\text { In vitro: ELISA; } \\
\text { immunohistochemistry; } \\
\text { immunoblot } \\
\text { In vivo: T maze test; } \\
\text { MWM test; EAE }{ }^{19} \text { score }\end{array}$ & [95] \\
\hline Tau & $\begin{array}{l}\operatorname{Tau}(379-408) \\
{[\mathrm{p} 396 / 404]}\end{array}$ & 3xTg-AD mice & $\begin{array}{l}\text { s.c. } / x 4 / 2 \mathrm{w} \text { or } 4 \mathrm{w} \\
\text { intervals }\end{array}$ & $\begin{array}{c}\text { In vitro: ELISA; } \\
\text { immunohistochemistry; } \\
\text { Western blot } \\
\text { In vivo: Rotarod test; } \\
\text { RAWM test; close field } \\
\text { symmetrical maze; } \\
\text { locomotor activity; } \\
\text { traverse beam test }\end{array}$ & [100] \\
\hline
\end{tabular}


Table 2. Cont.

\begin{tabular}{|c|c|c|c|c|c|}
\hline Target & Peptide Epitope & Animal Model & $\begin{array}{c}\text { Vaccination Scheme } \\
\text { (Administration } \\
\text { Route/Doses/Time } \\
\text { Intervals) }\end{array}$ & $\begin{array}{l}\text { Methods for Evaluating } \\
\text { Vaccination Efficacy }\end{array}$ & Reference \\
\hline Tau & $\begin{array}{c}\mathrm{pTau30} \\
{[\mathrm{p} 202 / 205 / 238 / 262],} \\
\mathrm{pTau31} \\
{[\mathrm{p} 202 / 205 / 396 / 404],} \\
\mathrm{pTau35} \\
{[\mathrm{p} 238 / 262 / 396 / 404]}\end{array}$ & TauP301S mice & $-/ \times 4 /-$ & $\begin{array}{l}\text { In vitro: ELISA; ELISpot; } \\
\text { immunohistochemistry } \\
\text { In vivo: Rotarod test; } \\
\text { hind-limb clasping test; } \\
\text { grip strength test; } \\
\text { kyphosis test }\end{array}$ & [97] \\
\hline$\alpha$-Syn & $\begin{array}{c}\alpha-\operatorname{Syn}(85-99) \\
\alpha-\operatorname{Syn}(109-126) \\
\alpha-\operatorname{Syn}(126-140)\end{array}$ & B6SJL mice & s.c. $/ x 4 / 2 \mathrm{w}$ interval & $\begin{array}{l}\text { In vitro: ELISA; ELISpot; } \\
\text { immunohistochemistry; } \\
\text { Western blot }\end{array}$ & [111] \\
\hline$\alpha-$ Syn & $\begin{array}{c}\text { middle region: } C^{9} \\
\text { GGKNEEGAPQ } \\
\text { (PD1) } \\
\text { N-terminal: } \\
\text { MDVFMKGLGGC } \\
\text { (PD2) } \\
\text { C-terminal: } \\
\text { CGGEGYQDYEPEA } \\
\text { (PD3) }\end{array}$ & SNCA-OVX mice & $\begin{array}{c}\text { s.c. } / x 3, \times 4, \times 5, x 14 / 2 \\
\text { w or } 4 \mathrm{w} \text { intervals }\end{array}$ & $\begin{array}{c}\text { In vitro: ELISA; } \\
\text { immuno-histochemistry; } \\
\text { Western blot; AS-PLA } 20 \\
\text { In vivo: Rotarod test; } \\
\text { locomotor activity; } \\
\text { digitized gait } \\
\text { assessment; inverted } \\
\text { screen test }\end{array}$ & [43] \\
\hline \multicolumn{6}{|c|}{$\begin{array}{l}1 \text { i.m./s.c./i.d.: intramuscular/subcutaneous/intradermal route of administration. }{ }^{2} \text { MTT: } 3 \text { - }[4,5-\text { dimethylthiazol-2-yl]-2,5 diphenyl } \\
\text { tetrazolium bromide. }{ }^{3} \text { TUNEL: Terminal deoxynucleotidyl transferase dUTP nick end labeling. }{ }^{4} \text { ROS: Reactive oxygen species. }{ }^{5} \text { MRI: } \\
\text { Magnetic resonance imaging. }{ }^{6} \text { NOR: Novel object recognition. }{ }^{7} \text { MWM: Morris water maze. }{ }^{8} \text { TEM: Transmission electron microscopy. }{ }^{9} \\
\text { Amino acids shown with the one-letter code. }{ }^{10} \text { OF: Open field. }{ }^{11} \text { SA: Spontaneous alternation. }{ }^{12} \text { NLR: Novel location recognition. }{ }^{13} \text { PET: } \\
\text { Positron emission tomography. }{ }^{14} \text { SPR: Surface plasmon resonance. }{ }^{15} \text { p: Phosphorylated amino acid residue(s) at a specific site in the } \\
\text { protein sequence. }{ }^{16} \text { EP1, EP2: Special peptide epitopes of A } \beta \text { oligomers selected with phage display from random peptide libraries. }{ }^{17} \\
\text { RAWM: Radial arm water maze. }{ }^{18} \text { NPR: Novel placement recognition. }{ }^{19} \text { EAE: Experimental autoimmune encephalomyelitis. }{ }^{20} \text { AS-PLA: } \\
\text { Alpha-synuclein proximity ligation assay. }\end{array}$} \\
\hline
\end{tabular}

The interval between doses has been reported to affect vaccine efficacy, but the optimal time for boosting remains to be identified. The majority of studies employed a time interval of 2-4 weeks, but 1.5 month- [78,92] or even 5 month- [80] intervals have also been reported. The age of animals at the beginning of vaccination, which may be correlated with progress in the development of brain pathology, has been also taken into account/investigated in some studies $[70,81]$.

\subsection{Methods for Assessing Vaccination Efficacy}

Vaccination efficacy is usually evaluated through the investigation of humoral responses, histological characteristics, and behavioral/cognitive changes induced in vaccinated animals (Table 2).

As a rule, in vitro immunochemical methods are employed for evaluating humoral immune responses. ELISA remains the "golden standard" technique employed in all studies to verify the presence, determine the avidity (titer) and investigate the characteristics of immunogen-specific antibodies in the sera of immunized animals. Concerning characteristics of the antibodies elicited, it should be noticed that although a high titer is considered a prerequisite for clinical efficacy, a solid correlation between these two parameters remains to be unequivocally proved [5,80]. ELISA has also been used, although more rarely, for isotyping the developed antibodies $[40,75,92,94]$, since the antibody class/subclass may provide interesting information concerning Th1/Th2 immune response [5]. Antibodies were also characterized with dot blot [75,92]. On the other hand, the presence and/or levels of key biomarkers in tissue sections, tissue lysates, or biological fluids is often monitored with immunohistochemistry, Western blot, or ELISA upon completion of vaccination. Another parameter often investigated is the pattern of cytokine production after vaccination, which is usually monitored with ELISpot $[34,73,74,83,97,111]$. 
In vivo behavioral analysis tests are usually employed to give insight into the vaccine effects on the cognitive functions of the vaccinated animals [125]. The most commonly used among them include the T maze/Y maze tests, used for assessing the spatial short-term memory and alternation of behavior, the Morris Water Maze (MWM) test, a robust and reliable test of spatial learning for rodents that is strongly correlated with hippocampal synaptic plasticity, the Novel Object Recognition (NOR) test, a relatively low-stress, efficient test for learning and memory in mice, appropriate for the detection of neuropsychological changes following pharmacological, biological, or genetic manipulations and based on the spontaneous tendency of mice to exhibit more interactions with a novel object rather than a familiar one. Other tests used complementarily with the aforementioned ones are the Open Field (OF) test [81], the Spontaneous Alternation (SA) test [81], the Novel Location Recognition (NLR) test [81], the Rotarod test [43,92,97,100], the radial arm water maze (RAWM) test [34,100], the Hind-limb clasping test [97], the grip strength test [97], the Locomotor activity test $[43,100]$, the inverted screen test [43], the digitized gait assessment test [43], and the Experimental Autoimmune Encephalomyelitis (EAE) score for examining neurological deficits and paralysis [95].

\section{Discussion}

The development of peptide-based active immunotherapies/vaccines for the treatment of neurodegenerative diseases has been the objective of many research endeavors for the last two decades [4,25]. Since the pioneering work of Schenk et al. [58], who vaccinated PDAPP transgenic mice overexpressing mutant human APP with pre-aggregated A $\beta(1-42)$ as a putative active immunotherapeutic strategy against $A D$, several other vaccines have been described; these vaccines have been mainly based on the most popular scenarios concerning the pathogenesis of neurodegeneration, i.e., amyloidosis and tauopathies [126] as well as synucleinopathies [46]. Though a monoclonal antibody, i.e., a passive immunotherapeutic agent, has been the first immunotherapy to be approved by the FDA for patients with AD [20], vaccines can eventually prove to be an advantageous treatment that can be widely used against neurodegeneration [3]. In fact, in comparison with passive immunotherapies, vaccination is not only well affordable for a large number of population groups, but it moreover induces a polyclonal response, including different antibody specificities and subclasses, which may offer better and longer-lasting protection than that of passively administered monoclonal antibodies [5]. For this reason, despite several setbacks, attempts to develop suitable vaccines for neurodegenerative diseases have practically never stopped.

The first clinical trial of a vaccine for AD (AN1792 vaccine) was based on intact A $\beta(1-$ 42); clinical trials were finally abandoned, due to the development of severe adverse effects in some of the participating patients. The adverse reactions were associated, at least partly, with a T-cell-mediated autoimmune response. In order to avoid autoimmune T-cell activation, short $\mathrm{N}$-terminal A $\beta$-peptide fragments that corresponded to B-cell peptide epitopes were later used as antigens instead of the full-length peptide [5]. Careful selection/design of peptide (neo)epitope(s), which may ideally be recognized by the host's B- but not T-cells [127], is a parameter of utmost importance for achieving the safety and efficacy necessary for a peptide-based vaccine against AD and other neurodegenerative diseases. In addition to the selection of suitable B-cell peptide epitopes, the safety and efficacy of a peptide-based vaccine depend on various other parameters, including the carriers/delivery systems that usually provide the external T-cell epitopes and/or facilitate final access to the in vivo biological target as well as the adjuvants ensuring enhanced immune response of the desired type, i.e., Th2-biased [5,126]. Formulation systems, in general, consist of factors that may greatly affect the final outcome of peptide-based vaccination; to support this, it is noteworthy mentioning that a new phase II clinical trial was announced for an optimized formulation of the $\alpha$-syn peptide-based vaccine, PD01, a few months ago [108]. Concerning the pre-clinical in vivo animal studies, it should be noticed that specific parameters, such as the animal model, the specific vaccine excipients, and the vaccination schemes used $[34,81,84,126]$ might have highly contributed to the overall outcome [70,72]. 
This issue may be responsible for the non-optimal results obtained in the subsequent trials with human subjects and should be carefully considered in future endeavors.

Future Perspectives: After two decades of research in the field, the development of successful peptide-based vaccines for neurodegenerative diseases seems to be a very ambitious, but not impossible goal to achieve. Further research on the design and selection of appropriate B-cell peptide epitopes of $\mathrm{A} \beta$ (including safe conformational epitopes of $A \beta$ oligomers), tau, and $\alpha$-syn, which would be capable of inducing antibodies of high titer and optimal features, and prevent any undesirable T-cell autoimmune responses, may eventually result in vaccines of great efficacy and safety. Moreover, using simultaneously multiple peptide epitopes of $A \beta$, tau, and $\alpha$-syn may enhance the overall vaccine efficacy, in comparison with monotherapy, as several literature reports have pointed out $[5,14]$. Peptide-based vaccines targeting biomolecules other than $\mathrm{A} \beta$, tau, or $\alpha$-syn $[1,14,18]$ may also prove to be successful, while combinations of vaccines and passive immunotherapies (antibodies) might be advantageous [14]. Research achievements in other related areas are expected to stimulate and greatly assist research toward novel peptide-based vaccines for neurodegenerative diseases. Thus, results of passive immunotherapy with anti-A $\beta$ monoclonal antibodies are expected to provide valuable information concerning the immunochemical features, such as the epitope specificity and subclass that the vaccineinduced antibodies should ideally show [5]. Moreover, numerous peptide-based vaccines, including vaccines targeting acquired immune deficiency syndrome (AIDS), malaria, and, most recently, coronavirus disease 2019 (COVID-19), are currently under development [25], while much work has been accomplished so far toward design and development of peptidebased anticancer vaccines [128]. Interestingly, short peptides targeting Toll-like receptors have been recently proposed as promising new adjuvants in vaccine research $[129,130]$. In addition, deeper insight into less-studied risk factors for neurodegenerative diseases [131] and a better understanding of the biological mechanisms through which nutritional, environmental, and lifestyle parameters may affect neuropathology (similar with their influence on pathology/epidemiology of, e.g., neoplastic diseases, [132]), is expected to broaden the array of putative therapeutic targets for fighting neurodegeneration. Preliminary findings that associate gut microbiome with brain diseases [133,134], e.g., PD, through several ways including the production of proteins similar to misfolded $\alpha$-syn by the intestine microbes (which may further serve as a human-protein misfolding-template), are just an example of how diverse future perspectives in this area may be. On the other hand, recent research efforts have focused on the discovery of novel biomarkers, eventually including personalized markers, for assessing onset and/or progression of neurodegenerative diseases [1,8,135]; diagnostic and/or prognostic biomarkers are especially needed in the area of synucleinopathies [14]. Moreover, much research has been recently directed toward developing improved analytical methods for reliable measurement of established biomarkers, each one alone or often in combination, in easily available biological fluids, such as plasma, urine, or saliva [1,136-138]. Success in the discovery of novel biomarkers and development of highly reliable and easy to perform methods for biomarker analysis will definitely facilitate the evaluation of candidate peptide-based vaccines for neurodegenerative diseases and accelerate further progress.

\section{Conclusions}

Neurodegenerative diseases are very complex and heterogeneous in nature, and their treatment remains a great challenge for the community. Interest in immunotherapeutic approaches has been rekindled after recent approval (even amid some controversy) of a monoclonal antibody as the first, passive, immunotherapy against AD by the FDA. Efforts to develop active immunotherapies, i.e., vaccines, on the other hand, have actually never been abandoned, despite initial setbacks. The vast majority of vaccines under development are peptide-based ones and employ specific peptide epitopes (or, specially designed mimotopes) of biomolecular targets associated with the neurodegeneration onset/progress, such as the polypeptide $A \beta$, or the proteins tau and $\alpha$-syn. The overall efficacy and safety 
of peptide-based vaccines are greatly influenced by specific factors, such as the exact peptide epitope and the formulation components used. Further advances, including the discovery of novel biomolecular targets linked with neurodegeneration, identification of peptide-epitopes on the former through high-resolution structural biology methods or immunoinformatics, and the development of improved formulation systems are expected to accelerate/facilitate research in this particulate area of immunotherapy, aiming ultimately at clinical exploitation.

Author Contributions: Literature collection and draft preparation, V.V.; contribution to literature search and draft writing, A.E. and C.-E.K.; contribution to literature search, C.Z.; conceptualization, review and editing of the manuscript, E.L. All authors have read and agreed to the published version of the manuscript.

Funding: This research received no external funding.

Conflicts of Interest: The authors declare no conflict of interest.

\section{References}

1. Mortada, I.; Farah, R.; Nabha, S.; Ojcius, D.M.; Fares, Y.; Almawi, W.Y.; Sadier, N.S. Immunotherapies for Neurodegenerative Diseases. Front. Neurol. 2021, 12, 654739. [CrossRef]

2. Drouin, E.; Drouin, G. The first report of Alzheimer's disease. Lancet Neurol. 2017, 16, 687. [CrossRef]

3. Kwan, P.; Konno, H.; Chan, K.Y.; Baum, L. Rationale for the development of an Alzheimer's disease vaccine. Hum. Vaccines Immunother. 2020, 16, 645-653. [CrossRef]

4. Malonis, R.J.; Lai, J.R.; Vergnolle, O. Peptide-Based Vaccines: Current Progress and Future Challenges. Chem. Rev. 2020, 120, 3210-3229. [CrossRef]

5. Mantile, F.; Prisco, A. Vaccination against $\beta$-Amyloid as a Strategy for the Prevention of Alzheimer's Disease. Biology 2020, 9, 425. [CrossRef]

6. Armstrong, R.A. What causes alzheimer's disease? Folia Neuropathol. 2013, 51, 169-188. [CrossRef]

7. Yan, D.; Zhang, Y.; Liu, L.; Yan, H. Pesticide exposure and risk of Alzheimer's disease: A systematic review and meta-analysis. Sci. Rep. 2016, 6, 32222. [CrossRef] [PubMed]

8. Stoiljkovic, M.; Horvath, T.L.; Hajós, M. Therapy for Alzheimer's disease: Missing targets and functional markers? Ageing Res. Rev. 2021, 68, 101318. [CrossRef]

9. Bertram, L.; Tanzi, R.E. The genetics of Alzheimer's disease. Prog. Mol. Biol. Transl. Sci. 2012, 107, 79-100. [CrossRef] [PubMed]

10. Selkoe, D.J.; Hardy, J. The amyloid hypothesis of Alzheimer's disease at 25 years. EMBO Mol. Med. 2016, 8, 595-608. [CrossRef]

11. Hoskin, J.L.; Sabbagh, M.N.; Al-Hasan, Y.; Decourt, B. Tau immunotherapies for Alzheimer's disease. Expert Opin. Investig. Drugs 2019, 28, 545-554. [CrossRef]

12. Eisele, Y.S.; Monteiro, C.; Fearns, C.; Encalada, S.E.; Wiseman, R.L.; Powers, E.T.; Kelly, J.W. Targeting protein aggregation for the treatment of degenerative diseases. Nat. Rev. Drug Discov. 2015, 14, 759-780. [CrossRef]

13. Spires-Jones, T.L.; Hyman, B.T. The intersection of amyloid beta and tau at synapses in Alzheimer's disease. Neuron 2014, 82, 756-771. [CrossRef]

14. Kwon, S.; Iba, M.; Kim, C.; Masliah, E. Immunotherapies for Aging-Related Neurodegenerative Diseases-Emerging Perspectives and New Targets. Neurother. J. Am. Soc. Exp. Neurother. 2020, 17, 935-954. [CrossRef]

15. Lashuel, H.A.; Overk, C.R.; Oueslati, A.; Masliah, E. The many faces of $\alpha$-synuclein: From structure and toxicity to therapeutic target. Nat. Rev. Neurosci. 2013, 14, 38-48. [CrossRef] [PubMed]

16. DeTure, M.A.; Dickson, D.W. The neuropathological diagnosis of Alzheimer's disease. Mol. Neurodegener. 2019, 14, 32. [CrossRef] [PubMed]

17. Twohig, D.; Nielsen, H.M. $\alpha$-synuclein in the pathophysiology of Alzheimer's disease. Mol. Neurodegener. 2019, 14, 23. [CrossRef]

18. Wells, C.; Brennan, S.; Keon, M.; Ooi, L. The role of amyloid oligomers in neurodegenerative pathologies. Int. J. Biol. Macromol. 2021, 181, 582-604. [CrossRef]

19. Jack, C.R., Jr. Preclinical Alzheimer's disease: A valid concept. Lancet Neurol. 2020, 19, 31. [CrossRef]

20. Biogen's Alzheimer's Drug Gets FDA Approval, Mixed Reviews. Available online: https://www.the-scientist.com/newsopinion/biogen-s-alzheimer-s-drug-gets-fda-approval-mixed-reviews-68851 (accessed on 20 October 2021).

21. Sevigny, J.; Chiao, P.; Bussière, T.; Weinreb, P.H.; Williams, L.; Maier, M.; Dunstan, R.; Salloway, S.; Chen, T.; Ling, Y.; et al. The antibody aducanumab reduces A $\beta$ plaques in Alzheimer's disease. Nature 2016, 537, 50-56. [CrossRef]

22. Tolar, M.; Abushakra, S.; Hey, J.A.; Porsteinsson, A.; Sabbagh, M. Aducanumab, gantenerumab, BAN2401, and ALZ-801-the first wave of amyloid-targeting drugs for Alzheimer's disease with potential for near term approval. Alzheimer's Res. Ther. 2020, 12, 95. [CrossRef] 
23. Knopman, D.S.; Jones, D.T.; Greicius, M.D. Failure to demonstrate efficacy of aducanumab: An analysis of the EMERGE and ENGAGE trials as reported by Biogen, December 2019. Alzheimer's Dement. J. Alzheimer's Assoc. 2021, 17, 696-701. [CrossRef] [PubMed]

24. Mullard, A. Controversial Alzheimer's drug approval could affect other diseases. Nature 2021, 595, 162-163. [CrossRef] [PubMed]

25. Apostolopoulos, V.; Bojarska, J.; Chai, T.-T.; Elnagdy, S.; Kaczmarek, K.; Matsoukas, J.; New, R.; Parang, K.; Lopez, O.P.; Parhiz, H.; et al. A Global Review on Short Peptides: Frontiers and Perspectives. Molecules 2021, 26, 430. [CrossRef] [PubMed]

26. Valera, E.; Spencer, B.; Masliah, E. Immunotherapeutic Approaches Targeting Amyloid- $\beta$, $\alpha$-Synuclein, and Tau for the Treatment of Neurodegenerative Disorders. Neurother. J. Am. Soc. Exp. Neurother. 2016, 13, 179-189. [CrossRef] [PubMed]

27. Bard, F.; Cannon, C.; Barbour, R.; Burke, R.L.; Games, D.; Grajeda, H.; Guido, T.; Hu, K.; Huang, J.; Johnson-Wood, K.; et al. Peripherally administered antibodies against amyloid beta-peptide enter the central nervous system and reduce pathology in a mouse model of Alzheimer disease. Nat. Med. 2000, 6, 916-919. [CrossRef] [PubMed]

28. Freir, D.B.; Nicoll, A.J.; Klyubin, I.; Panico, S.; Mc Donald, J.M.; Risse, E.; Asante, E.A.; Farrow, M.A.; Sessions, R.B.; Saibil, H.R.; et al. Interaction between prion protein and toxic amyloid $\beta$ assemblies can be therapeutically targeted at multiple sites. Nat. Commun. 2011, 2, 336. [CrossRef] [PubMed]

29. Corbett, G.T.; Wang, Z.; Hong, W.; Colom-Cadena, M.; Rose, J.; Liao, M.; Asfaw, A.; Hall, T.C.; Ding, L.; DeSousa, A.; et al. PrP is a central player in toxicity mediated by soluble aggregates of neurodegeneration-causing proteins. Acta Neuropathol. 2020, 139, 503-526. [CrossRef] [PubMed]

30. Boutajangout, A.; Zhang, W.; Kim, J.; Abdali, W.A.; Prelli, F.; Wisniewski, T. Passive Immunization with a Novel Monoclonal Anti-PrP Antibody TW1 in an Alzheimer's Mouse Model With Tau Pathology. Front. Aging Neurosci. 2021, 13, 640677. [CrossRef]

31. Zhou, Q.; Mareljic, N.; Michaelsen, M.; Parhizkar, S.; Heindl, S.; Nuscher, B.; Farny, D.; Czuppa, M.; Schludi, C.; Graf, A.; et al. Active poly-GA vaccination prevents microglia activation and motor deficits in a C9orf72 mouse model. EMBO Mol. Med. 2020, 12, e10919. [CrossRef]

32. Ramsingh, A.I.; Manley, K.; Rong, Y.; Reilly, A.; Messer, A. Transcriptional dysregulation of inflammatory/immune pathways after active vaccination against Huntington's disease. Hum. Mol. Genet. 2015, 24, 6186-6197. [CrossRef]

33. Agrawal, N.; Skelton, A.A. Structure and Function of Alzheimer's Amyloid ßeta Proteins from Monomer to Fibrils: A Mini Review. Protein J. 2019, 38, 425-434. [CrossRef]

34. Joly-Amado, A.; Davtyan, H.; Serraneau, K.; Jules, P.; Zitnyar, A.; Pressman, E.; Zagorski, K.; Antonyan, T.; Hovakimyan, A.; Paek, H.J.; et al. Active immunization with tau epitope in a mouse model of tauopathy induced strong antibody response together with improvement in short memory and pSer396-tau pathology. Neurobiol. Dis. 2020, 134, 104636. [CrossRef] [PubMed]

35. Zeng, Y.; Yang, J.; Zhang, B.; Gao, M.; Su, Z.; Huang, Y. The structure and phase of tau: From monomer to amyloid filament. Cell. Mol. Life Sci. CMLS 2021, 78, 1873-1886. [CrossRef] [PubMed]

36. Fitzpatrick, A.W.P.; Falcon, B.; He, S.; Murzin, A.G.; Murshudov, G.; Garringer, H.J.; Crowther, R.A.; Ghetti, B.; Goedert, M.; Scheres, S.H.W. Cryo-EM structures of tau filaments from Alzheimer's disease. Nature 2017, 547, 185-190. [CrossRef] [PubMed]

37. Al-Hilaly, Y.K.; Foster, B.E.; Biasetti, L.; Lutter, L.; Pollack, S.J.; Rickard, J.E.; Storey, J.M.D.; Harrington, C.R.; Xue, W.F.; Wischik, C.M.; et al. Tau (297-391) forms filaments that structurally mimic the core of paired helical filaments in Alzheimer's disease brain. FEBS Lett. 2020, 594, 944-950. [CrossRef] [PubMed]

38. Rösler, T.W.; Marvian, A.T.; Brendel, M.; Nykänen, N.P.; Höllerhage, M.; Schwarz, S.C.; Hopfner, F.; Koeglsperger, T.; Respondek, G.; Schweyer, K.; et al. Four-repeat tauopathies. Prog. Neurobiol. 2019, 180, 101644. [CrossRef] [PubMed]

39. Augustinack, J.C.; Schneider, A.; Mandelkow, E.M.; Hyman, B.T. Specific tau phosphorylation sites correlate with severity of neuronal cytopathology in Alzheimer's disease. Acta Neuropathol. 2002, 103, 26-35. [CrossRef]

40. Ji, M.; Xie, X.; Liu, D.-Q.; Lu, S.; Zhang, L.; Huang, Y.-R.; Liu, R. Engineered hepatitis B core virus-like particle carrier for precise and personalized Alzheimer's disease vaccine preparation via fixed-point coupling. Appl. Mater. Today 2020, $19,100575$. [CrossRef]

41. Stefanis, L.; Emmanouilidou, E.; Pantazopoulou, M.; Kirik, D.; Vekrellis, K.; Tofaris, G.K. How is alpha-synuclein cleared from the cell? J. Neurochem. 2019, 150, 577-590. [CrossRef] [PubMed]

42. Huang, M.; Wang, B.; Li, X.; Fu, C.; Wang, C.; Kang, X. $\alpha$-Synuclein: A Multifunctional Player in Exocytosis, Endocytosis, and Vesicle Recycling. Front. Neurosci. 2019, 13, 28. [CrossRef]

43. Doucet, M.; El-Turabi, A.; Zabel, F.; Hunn, B.H.M.; Bengoa-Vergniory, N.; Cioroch, M.; Ramm, M.; Smith, A.M.; Gomes, A.C.; Cabral de Miranda, G.; et al. Preclinical development of a vaccine against oligomeric alpha-synuclein based on virus-like particles. PLoS ONE 2017, 12, e0181844. [CrossRef] [PubMed]

44. Bendor, J.T.; Logan, T.P.; Edwards, R.H. The function of $\alpha$-synuclein. Neuron 2013, 79, 1044-1066. [CrossRef]

45. Wong, Y.C.; Krainc, D. $\alpha$-synuclein toxicity in neurodegeneration: Mechanism and therapeutic strategies. Nat. Med. 2017, 23, 1-13. [CrossRef] [PubMed]

46. Jamal, F. Immunotherapies Targeting $\alpha$-Synuclein in Parkinson Disease. Fed. Pract. Health Care Prof. VA DoD PHS 2020, 37, 375-379. [CrossRef]

47. Plotkin, S.S.; Cashman, N.R. Passive immunotherapies targeting A $\beta$ and tau in Alzheimer's disease. Neurobiol. Dis. 2020, 144, 105010. [CrossRef]

48. Baig, M.H.; Ahmad, K.; Saeed, M.; Alharbi, A.M.; Barreto, G.E.; Ashraf, G.M.; Choi, I. Peptide based therapeutics and their use for the treatment of neurodegenerative and other diseases. Biomed. Pharmacother. 2018, 103, 574-581. [CrossRef] [PubMed] 
49. Santos, J.; Gracia, P.; Navarro, S.; Peña-Díaz, S.; Pujols, J.; Cremades, N.; Pallarès, I.; Ventura, S. $\alpha$-Helical peptidic scaffolds to target $\alpha$-synuclein toxic species with nanomolar affinity. Nat. Commun. 2021, 12, 3752. [CrossRef] [PubMed]

50. Hashimoto, Y.; Niikura, T.; Tajima, H.; Yasukawa, T.; Sudo, H.; Ito, Y.; Kita, Y.; Kawasumi, M.; Kouyama, K.; Doyu, M.; et al. A rescue factor abolishing neuronal cell death by a wide spectrum of familial Alzheimer's disease genes and Abeta. Proc. Natl. Acad. Sci. USA 2001, 98, 6336-6341. [CrossRef] [PubMed]

51. Benaki, D.; Zikos, C.; Evangelou, A.; Livaniou, E.; Vlassi, M.; Mikros, E.; Pelecanou, M. Solution structure of humanin, a peptide against Alzheimer's disease-related neurotoxicity. Biochem. Biophys. Res. Commun. 2005, 329, 152-160. [CrossRef]

52. Zou, P.; Ding, Y.; Sha, Y.; Hu, B.; Nie, S. Humanin peptides block calcium influx of rat hippocampal neurons by altering fibrogenesis of Abeta(1-40). Peptides 2003, 24, 679-685. [CrossRef]

53. Price, D.; Dorandish, S.; Williams, A.; Iwaniec, B.; Stephens, A.; Marshall, K.; Guthrie, J.; Heyl, D.; Evans, H.G. Humanin Blocks the Aggregation of Amyloid- $\beta$ Induced by Acetylcholinesterase, an Effect Abolished in the Presence of IGFBP-3. Biochemistry 2020, 59, 1981-2002. [CrossRef] [PubMed]

54. Skwarczynski, M.; Toth, I. Peptide-based synthetic vaccines. Chem. Sci. 2016, 7, 842-854. [CrossRef] [PubMed]

55. Sanchez-Trincado, J.L.; Gomez-Perosanz, M.; Reche, P.A. Fundamentals and Methods for T- and B-Cell Epitope Prediction. J. Immunol. Res. 2017, 2017, 2680160. [CrossRef]

56. Fleri, W.; Paul, S.; Dhanda, S.K.; Mahajan, S.; Xu, X.; Peters, B.; Sette, A. The Immune Epitope Database and Analysis Resource in Epitope Discovery and Synthetic Vaccine Design. Front. Immunol. 2017, 8, 278. [CrossRef]

57. Raoufi, E.; Hemmati, M.; Eftekhari, S.; Khaksaran, K.; Mahmodi, Z.; Farajollahi, M.M.; Mohsenzadegan, M. Epitope Prediction by Novel Immunoinformatics Approach: A State-of-the-art Review. Int. J. Pept. Res. Ther. 2020, 26, 1155-1163. [CrossRef] [PubMed]

58. Schenk, D.; Barbour, R.; Dunn, W.; Gordon, G.; Grajeda, H.; Guido, T.; Hu, K.; Huang, J.; Johnson-Wood, K.; Khan, K.; et al. Immunization with amyloid-beta attenuates Alzheimer-disease-like pathology in the PDAPP mouse. Nature 1999, 400, 173-177. [CrossRef]

59. Nicoll, J.A.R.; Buckland, G.R.; Harrison, C.H.; Page, A.; Harris, S.; Love, S.; Neal, J.W.; Holmes, C.; Boche, D. Persistent neuropathological effects 14 years following amyloid- $\beta$ immunization in Alzheimer's disease. Brain J. Neurol. 2019, 142, 2113-2126. [CrossRef] [PubMed]

60. Wisniewski, T.; Goñi, F. Immunotherapeutic approaches for Alzheimer's disease. Neuron 2015, 85, 1162-1176. [CrossRef] [PubMed]

61. Marciani, D.J. Promising Results from Alzheimer's Disease Passive Immunotherapy Support the Development of a Preventive Vaccine. Research 2019, 2019, 5341375. [CrossRef] [PubMed]

62. Mo, J.J.; Li, J.Y.; Yang, Z.; Liu, Z.; Feng, J.S. Efficacy and safety of anti-amyloid- $\beta$ immunotherapy for Alzheimer's disease: A systematic review and network meta-analysis. Ann. Clin. Transl. Neurol. 2017, 4, 931-942. [CrossRef]

63. Farlow, M.R.; Andreasen, N.; Riviere, M.E.; Vostiar, I.; Vitaliti, A.; Sovago, J.; Caputo, A.; Winblad, B.; Graf, A. Long-term treatment with active A $\beta$ immunotherapy with CAD106 in mild Alzheimer's disease. Alzheimer's Res. Ther. 2015, 7, 23. [CrossRef]

64. Vandenberghe, R.; Riviere, M.E.; Caputo, A.; Sovago, J.; Maguire, R.P.; Farlow, M.; Marotta, G.; Sanchez-Valle, R.; Scheltens, P.; Ryan, J.M.; et al. Active A $\beta$ immunotherapy CAD106 in Alzheimer's disease: A phase 2b study. Alzheimer's Dement. 2017, 3, 10-22. [CrossRef] [PubMed]

65. Pasquier, F.; Sadowsky, C.; Holstein, A.; Leterme Gle, P.; Peng, Y.; Jackson, N.; Fox, N.C.; Ketter, N.; Liu, E.; Ryan, J.M. Two Phase 2 Multiple Ascending-Dose Studies of Vanutide Cridificar (ACC-001) and QS-21 Adjuvant in Mild-to-Moderate Alzheimer's Disease. J. Alzheimer's Dis. 2016, 51, 1131-1143. [CrossRef]

66. Wang, C.Y.; Wang, P.N.; Chiu, M.J.; Finstad, C.L.; Lin, F.; Lynn, S.; Tai, Y.H.; De Fang, X.; Zhao, K.; Hung, C.H.; et al. UB-311, a novel UBITh $\left({ }^{\circledR}\right)$ amyloid $\beta$ peptide vaccine for mild Alzheimer's disease. J. Alzheimer's Dis. 2017, 3, 262-272. [CrossRef] [PubMed]

67. Lacosta, A.M.; Pascual-Lucas, M.; Pesini, P.; Casabona, D.; Pérez-Grijalba, V.; Marcos-Campos, I.; Sarasa, L.; Canudas, J.; Badi, H.; Monleón, I.; et al. Safety, tolerability and immunogenicity of an active anti-A $\beta(40)$ vaccine (ABvac40) in patients with Alzheimer's disease: A randomised, double-blind, placebo-controlled, phase I trial. Alzheimer's Res. Ther. 2018, 10, 12. [CrossRef]

68. Marciani, D.J. A retrospective analysis of the Alzheimer's disease vaccine progress-The critical need for new development strategies. J. Neurochem. 2016, 137, 687-700. [CrossRef]

69. Schneeberger, A.; Hendrix, S.; Mandler, M.; Ellison, N.; Bürger, V.; Brunner, M.; Frölich, L.; Mimica, N.; Hort, J.; Rainer, M.; et al. Results from a Phase II Study to Assess the Clinical and Immunological Activity of AFFITOPE ${ }^{\circledR}$ AD02 in Patients with Early Alzheimer's Disease. J. Prev. Alzheimer's Dis. 2015, 2, 103-114. [CrossRef]

70. Wang, J.C.; Zhu, K.; Zhang, H.Y.; Wang, G.Q.; Liu, H.Y.; Cao, Y.P. Early active immunization with A $\beta(3-10)-K L H$ vaccine reduces tau phosphorylation in the hippocampus and protects cognition of mice. Neural Regen. Res. 2020, 15, 519-527. [CrossRef] [PubMed]

71. Ding, L.; Meng, Y.; Zhang, H.Y.; Yin, W.C.; Yan, Y.; Cao, Y.P. Prophylactic active immunization with a novel epitope vaccine improves cognitive ability by decreasing amyloid plaques and neuroinflammation in APP/PS1 transgenic mice. Neurosci. Res. 2017, 119, 7-14. [CrossRef]

72. Zhang, X.Y.; Meng, Y.; Yan, X.J.; Liu, S.; Wang, G.Q.; Cao, Y.P. Immunization with Aß3-10-KLH vaccine improves cognitive function and ameliorates mitochondrial dysfunction and reduces Alzheimer's disease-like pathology in Tg-APPswe/PSEN1dE9 mice. Brain Res. Bull. 2021, 174, 31-40. [CrossRef] [PubMed] 
73. Yang, P.; Guo, Y.; Sun, Y.; Yu, B.; Zhang, H.; Wu, J.; Yu, X.; Wu, H.; Kong, W. Active immunization with norovirus P particle-based amyloid- $\beta$ chimeric protein vaccine induces high titers of anti-A $\beta$ antibodies in mice. BMC Immunol. 2019, 20,9. [CrossRef] [PubMed]

74. Fu, L.; Guo, Y.; Sun, Y.; Dong, Y.; Wu, J.; Yu, B.; Zhang, H.; Yu, X.; Wu, H.; Kong, W. A novel A $\beta$ epitope vaccine based on bacterium-like particle against Alzheimer's disease. Mol. Immunol. 2018, 101, 259-267. [CrossRef]

75. Sun, D.; Qiao, Y.; Jiang, X.; Li, P.; Kuai, Z.; Gong, X.; Liu, D.; Fu, Q.; Sun, L.; Li, H.; et al. Multiple Antigenic Peptide System Coupled with Amyloid Beta Protein Epitopes As An Immunization Approach to Treat Alzheimer's Disease. ACS Chem. Neurosci. 2019, 10, 2794-2800. [CrossRef]

76. Li, S.; Jin, Y.; Wang, C.; Chen, J.; Yu, W.; Jin, Y.; Lv, Z. Effects of a 15-amino-acid isoform of amyloid- $\beta$ expressed by silkworm pupae on B6C3-Tg Alzheimer's disease transgenic mice. J. Biotechnol. 2019, 296, 83-92. [CrossRef]

77. Liu, D.Q.; Lu, S.; Zhang, L.; Huang, Y.R.; Ji, M.; Sun, X.Y.; Liu, X.G.; Liu, R.T. Yeast-Based A $\beta 1-15$ Vaccine Elicits Strong Immunogenicity and Attenuates Neuropathology and Cognitive Deficits in Alzheimer's Disease Transgenic Mice. Vaccines 2020, 8, 351. [CrossRef]

78. Davtyan, H.; Hovakimyan, A.; Shabestari, S.K.; Antonyan, T.; Coburn, M.A.; Zagorski, K.; Chailyan, G.; Petrushina, I.; Svystun, O.; Danhash, E.; et al. Testing a MultiTEP-based combination vaccine to reduce A $\beta$ and tau pathology in Tau22/5xFAD bigenic mice. Alzheimer's Res. Ther. 2019, 11, 107. [CrossRef] [PubMed]

79. Petrushina, I.; Hovakimyan, A.; Harahap-Carrillo, I.S.; Davtyan, H.; Antonyan, T.; Chailyan, G.; Kazarian, K.; Antonenko, M.; Jullienne, A.; Hamer, M.M.; et al. Characterization and preclinical evaluation of the cGMP grade DNA based vaccine, AV-1959D to enter the first-in-human clinical trials. Neurobiol. Dis. 2020, 139, 104823. [CrossRef]

80. Mantile, F.; Capasso, A.; Villacampa, N.; Donnini, M.; Liguori, G.L.; Constantin, G.; De Berardinis, P.; Heneka, M.T.; Prisco, A. Vaccination with (1-11)E2 in alum efficiently induces an antibody response to $\beta$-amyloid without affecting brain $\beta$-amyloid load and microglia activation in 3xTg mice. Aging Clin. Exp. Res. 2021, 33, 1383-1387. [CrossRef]

81. Oberman, K.; Gouweleeuw, L.; Hoogerhout, P.; Eisel, U.L.M.; van Riet, E.; Schoemaker, R.G. Vaccination Prevented Short-Term Memory Loss, but Deteriorated Long-Term Spatial Memory in Alzheimer's Disease Mice, Independent of Amyloid- $\beta$ Pathology. J. Alzheimer's Dis. Rep. 2020, 4, 261-280. [CrossRef]

82. Baek, H.; Lee, C.J.; Choi, D.B.; Kim, N.S.; Kim, Y.S.; Ye, Y.J.; Kim, Y.S.; Kim, J.S.; Shim, I.; Bae, H. Bee venom phospholipase A2 ameliorates Alzheimer's disease pathology in A $\beta$ vaccination treatment without inducing neuro-inflammation in a 3xTg-AD mouse model. Sci. Rep. 2018, 8, 17369. [CrossRef]

83. Rosenberg, R.N.; Fu, M.; Lambracht-Washington, D. Active full-length DNA A $\beta(42)$ immunization in 3xTg-AD mice reduces not only amyloid deposition but also tau pathology. Alzheimer's Res. Ther. 2018, 10, 115. [CrossRef]

84. Yu, X.L.; Zhu, J.; Liu, X.M.; Xu, P.X.; Zhang, Y.; Liu, R.T. Vaccines targeting the primary amino acid sequence and conformational epitope of amyloid- $\beta$ had distinct effects on neuropathology and cognitive deficits in EAE/AD mice. Br. J. Pharmacol. 2020, 177, 2860-2871. [CrossRef]

85. Novak, P.; Schmidt, R.; Kontsekova, E.; Zilka, N.; Kovacech, B.; Skrabana, R.; Vince-Kazmerova, Z.; Katina, S.; Fialova, L.; Prcina, M.; et al. Safety and immunogenicity of the tau vaccine AADvac1 in patients with Alzheimer's disease: A randomised, double-blind, placebo-controlled, phase 1 trial. Lancet Neurol. 2017, 16, 123-134. [CrossRef]

86. Novak, P.; Kontsekova, E.; Zilka, N.; Novak, M. Ten Years of Tau-Targeted Immunotherapy: The Path Walked and the Roads Ahead. Front. Neurosci. 2018, 12, 798. [CrossRef] [PubMed]

87. Novak, P.; Schmidt, R.; Kontsekova, E.; Kovacech, B.; Smolek, T.; Katina, S.; Fialova, L.; Prcina, M.; Parrak, V.; Dal-Bianco, P.; et al. FUNDAMANT: An interventional 72-week phase 1 follow-up study of AADvac1, an active immunotherapy against tau protein pathology in Alzheimer's disease. Alzheimer's Res. Ther. 2018, 10, 108. [CrossRef] [PubMed]

88. Herline, K.; Drummond, E.; Wisniewski, T. Recent advancements toward therapeutic vaccines against Alzheimer's disease. Expert Rev. Vaccines 2018, 17, 707-721. [CrossRef] [PubMed]

89. Kontsekova, E.; Zilka, N.; Kovacech, B.; Skrabana, R.; Novak, M. Identification of structural determinants on tau protein essential for its pathological function: Novel therapeutic target for tau immunotherapy in Alzheimer's disease. Alzheimer's Res. Ther. 2014, 6, 45. [CrossRef]

90. Kontsekova, E.; Zilka, N.; Kovacech, B.; Novak, P.; Novak, M. First-in-man tau vaccine targeting structural determinants essential for pathological tau-tau interaction reduces tau oligomerisation and neurofibrillary degeneration in an Alzheimer's disease model. Alzheimer's Res. Ther. 2014, 6, 44. [CrossRef] [PubMed]

91. Davtyan, H.; Zagorski, K.; Rajapaksha, H.; Hovakimyan, A.; Davtyan, A.; Petrushina, I.; Kazarian, K.; Cribbs, D.H.; Petrovsky, N.; Agadjanyan, M.G.; et al. Alzheimer's disease Advax(CpG)- adjuvanted MultiTEP-based dual and single vaccines induce high-titer antibodies against various forms of tau and A $\beta$ pathological molecules. Sci. Rep. 2016, 6, 28912. [CrossRef]

92. Hovakimyan, A.; Antonyan, T.; Shabestari, S.K.; Svystun, O.; Chailyan, G.; Coburn, M.A.; Carlen-Jones, W.; Petrushina, I.; Chadarevian, J.P.; Zagorski, K.; et al. A MultiTEP platform-based epitope vaccine targeting the phosphatase activating domain (PAD) of tau: Therapeutic efficacy in PS19 mice. Sci. Rep. 2019, 9, 15455. [CrossRef]

93. Bittar, A.; Bhatt, N.; Kayed, R. Advances and considerations in AD tau-targeted immunotherapy. Neurobiol. Dis. 2020, $134,104707$. [CrossRef] 
94. Ji, M.; Xie, X.X.; Liu, D.Q.; Yu, X.L.; Zhang, Y.; Zhang, L.X.; Wang, S.W.; Huang, Y.R.; Liu, R.T. Hepatitis B core VLP-based mis-disordered tau vaccine elicits strong immune response and alleviates cognitive deficits and neuropathology progression in Tau.P301S mouse model of Alzheimer's disease and frontotemporal dementia. Alzheimer's Res. Ther. 2018, 10, 55. [CrossRef] [PubMed]

95. Benhamron, S.; Rozenstein-Tsalkovich, L.; Nitzan, K.; Abramsky, O.; Rosenmann, H. Phos-tau peptide immunization of amyloidtg-mice reduced non-mutant phos-tau pathology, improved cognition and reduced amyloid plaques. Exp. Neurol. 2018, 303, 48-58. [CrossRef] [PubMed]

96. Maphis, N.M.; Peabody, J.; Crossey, E.; Jiang, S.; Jamaleddin Ahmad, F.A.; Alvarez, M.; Mansoor, S.K.; Yaney, A.; Yang, Y.; Sillerud, L.O.; et al. QB Virus-like particle-based vaccine induces robust immunity and protects against tauopathy. NPJ Vaccines $2019,4,26$ [CrossRef] [PubMed]

97. Sun, Y.; Guo, Y.; Feng, X.; Fu, L.; Zheng, Y.; Dong, Y.; Zhang, Y.; Yu, X.; Kong, W.; Wu, H. Norovirus P particle-based tau vaccine-generated phosphorylated tau antibodies markedly ameliorate tau pathology and improve behavioral deficits in mouse model of Alzheimer's disease. Signal Transduct. Target. Ther. 2021, 6, 61. [CrossRef] [PubMed]

98. Shahpasand, K.; Sepehri Shamloo, A.; Nabavi, S.M.; Lu, P.K.; Zhou, X.Z. "Tau immunotherapy: Hopes and hindrances". Hum. Vaccines Immunother. 2018, 14, 277-284. [CrossRef] [PubMed]

99. Teng, I.T.; Li, X.; Yadikar, H.A.; Yang, Z.; Li, L.; Lyu, Y.; Pan, X.; Wang, K.K.; Tan, W. Identification and Characterization of DNA Aptamers Specific for Phosphorylation Epitopes of Tau Protein. J. Am. Chem. Soc. 2018, 140, 14314-14323. [CrossRef] [PubMed]

100. Rajamohamedsait, H.; Rasool, S.; Rajamohamedsait, W.; Lin, Y.; Sigurdsson, E.M. Prophylactic Active Tau Immunization Leads to Sustained Reduction in Both Tau and Amyloid- $\beta$ Pathologies in 3xTg Mice. Sci. Rep. 2017, 7, 17034. [CrossRef]

101. Almandoz-Gil, L.; Lindström, V.; Sigvardson, J.; Kahle, P.J.; Lannfelt, L.; Ingelsson, M.; Bergström, J. Mapping of Surface-Exposed Epitopes of In Vitro and In Vivo Aggregated Species of Alpha-Synuclein. Cell. Mol. Neurobiol. 2017, 37, 1217-1226. [CrossRef]

102. Li, X.; Koudstaal, W.; Fletcher, L.; Costa, M.; van Winsen, M.; Siregar, B.; Inganäs, H.; Kim, J.; Keogh, E.; Macedo, J.; et al. Naturally occurring antibodies isolated from PD patients inhibit synuclein seeding in vitro and recognize Lewy pathology. Acta Neuropathol. 2019, 137, 825-836. [CrossRef]

103. Mandaci, S.Y.; Caliskan, M.; Sariaslan, M.F.; Uversky, V.N.; Coskuner-Weber, O. Epitope region identification challenges of intrinsically disordered proteins in neurodegenerative diseases: Secondary structure dependence of $\alpha$-synuclein on simulation techniques and force field parameters. Chem. Biol. Drug Des. 2020, 96, 659-667. [CrossRef] [PubMed]

104. McFarthing, K.; Simuni, T. Clinical Trial Highlights: Targetting Alpha-Synuclein. J. Parkinson's Dis. 2019, 9, 5-16. [CrossRef] [PubMed]

105. Chatterjee, D.; Kordower, J.H. Immunotherapy in Parkinson's disease: Current status and future directions. Neurobiol. Dis. 2019, 132, 104587. [CrossRef] [PubMed]

106. Meissner, W.G.; Traon, A.P.; Foubert-Samier, A.; Galabova, G.; Galitzky, M.; Kutzelnigg, A.; Laurens, B.; Lührs, P.; Medori, R.; Péran, P.; et al. A Phase 1 Randomized Trial of Specific Active $\alpha$-Synuclein Immunotherapies PD01A and PD03A in Multiple System Atrophy. Mov. Disord. Off. J. Mov. Disord. Soc. 2020, 35, 1957-1965. [CrossRef]

107. Volc, D.; Poewe, W.; Kutzelnigg, A.; Lührs, P.; Thun-Hohenstein, C.; Schneeberger, A.; Galabova, G.; Majbour, N.; Vaikath, N.; El-Agnaf, O.; et al. Safety and immunogenicity of the $\alpha$-synuclein active immunotherapeutic PD01A in patients with Parkinson's disease: A randomised, single-blinded, phase 1 trial. Lancet Neurol. 2020, 19, 591-600. [CrossRef]

108. Affitope PD01A, PD03A. Available online: https://www.alzforum.org/therapeutics/affitope-pd01a-pd03a (accessed on 21 October 2021).

109. Sulzer, D.; Alcalay, R.N.; Garretti, F.; Cote, L.; Kanter, E.; Agin-Liebes, J.; Liong, C.; McMurtrey, C.; Hildebrand, W.H.; Mao, X.; et al. T cells from patients with Parkinson's disease recognize $\alpha$-synuclein peptides. Nature 2017, 546, 656-661. [CrossRef] [PubMed]

110. Masliah, E.; Rockenstein, E.; Adame, A.; Alford, M.; Crews, L.; Hashimoto, M.; Seubert, P.; Lee, M.; Goldstein, J.; Chilcote, T.; et al. Effects of alpha-synuclein immunization in a mouse model of Parkinson's disease. Neuron 2005, 46, 857-868. [CrossRef]

111. Ghochikyan, A.; Petrushina, I.; Davtyan, H.; Hovakimyan, A.; Saing, T.; Davtyan, A.; Cribbs, D.H.; Agadjanyan, M.G. Immunogenicity of epitope vaccines targeting different B cell antigenic determinants of human $\alpha$-synuclein: Feasibility study. Neurosci. Lett. 2014, 560, 86-91. [CrossRef] [PubMed]

112. Marciani, D.J. New Th2 adjuvants for preventive and active immunotherapy of neurodegenerative proteinopathies. Drug Discov. Today 2014, 19, 912-920. [CrossRef] [PubMed]

113. Lei, Y.; Zhao, F.; Shao, J.; Li, Y.; Li, S.; Chang, H.; Zhang, Y. Application of built-in adjuvants for epitope-based vaccines. PeerJ 2019, 6, e6185. [CrossRef] [PubMed]

114. Davtyan, H.; Ghochikyan, A.; Petrushina, I.; Hovakimyan, A.; Davtyan, A.; Poghosyan, A.; Marleau, A.M.; Movsesyan, N.; Kiyatkin, A.; Rasool, S.; et al. Immunogenicity, efficacy, safety, and mechanism of action of epitope vaccine (Lu AF20513) for Alzheimer's disease: Prelude to a clinical trial. J. Neurosci. Off. J. Soc. Neurosci. 2013, 33, 4923-4934. [CrossRef]

115. Qu, B.X.; Lambracht-Washington, D.; Fu, M.; Eagar, T.N.; Stüve, O.; Rosenberg, R.N. Analysis of three plasmid systems for use in DNA A beta 42 immunization as therapy for Alzheimer's disease. Vaccine 2010, 28, 5280-5287. [CrossRef]

116. Steeghs, L.; Keestra, A.M.; van Mourik, A.; Uronen-Hansson, H.; van der Ley, P.; Callard, R.; Klein, N.; van Putten, J.P. Differential activation of human and mouse Toll-like receptor 4 by the adjuvant candidate LpxL1 of Neisseria meningitidis. Infect. Immun. 2008, 76, 3801-3807. [CrossRef] 
117. Shi, S.; Zhu, H.; Xia, X.; Liang, Z.; Ma, X.; Sun, B. Vaccine adjuvants: Understanding the structure and mechanism of adjuvanticity. Vaccine 2019, 37, 3167-3178. [CrossRef]

118. Azmi, F.; Ahmad Fuaad, A.A.; Skwarczynski, M.; Toth, I. Recent progress in adjuvant discovery for peptide-based subunit vaccines. Hum. Vaccines Immunother. 2014, 10, 778-796. [CrossRef] [PubMed]

119. Lindblad, E.B. Aluminium adjuvants-In retrospect and prospect. Vaccine 2004, 22, 3658-3668. [CrossRef]

120. Oscherwitz, J.; Hankenson, F.C.; Yu, F.; Cease, K.B. Low-dose intraperitoneal Freund's adjuvant: Toxicity and immunogenicity in mice using an immunogen targeting amyloid-beta peptide. Vaccine 2006, 24, 3018-3025. [CrossRef]

121. Bashiri, S.; Koirala, P.; Toth, I.; Skwarczynski, M. Carbohydrate Immune Adjuvants in Subunit Vaccines. Pharmaceutics 2020, 12, 965. [CrossRef]

122. Kohyama, K.; Matsumoto, Y. Alzheimer's disease and immunotherapy: What is wrong with clinical trials? ImmunoTargets Ther. 2015, 4, 27-34. [CrossRef]

123. Petrovsky, N.; Cooper, P.D. Advax ${ }^{\mathrm{TM}}$, a novel microcrystalline polysaccharide particle engineered from delta inulin, provides robust adjuvant potency together with tolerability and safety. Vaccine 2015, 33, 5920-5926. [CrossRef]

124. Wang, Y.Q.; Bazin-Lee, H.; Evans, J.T.; Casella, C.R.; Mitchell, T.C. MPL Adjuvant Contains Competitive Antagonists of Human TLR4. Front. Immunol. 2020, 11, 577823. [CrossRef]

125. Sukoff Rizzo, S.J.; Crawley, J.N. Behavioral Phenotyping Assays for Genetic Mouse Models of Neurodevelopmental, Neurodegenerative, and Psychiatric Disorders. Annu. Rev. Anim. Biosci. 2017, 5, 371-389. [CrossRef]

126. Cacabelos, R. How plausible is an Alzheimer's disease vaccine? Expert Opin. Drug Discov. 2020, 15, 1-6. [CrossRef] [PubMed]

127. Schneeberger, A.; Mandler, M.; Otawa, O.; Zauner, W.; Mattner, F.; Schmidt, W. Development of AFFITOPE vaccines for Alzheimer's disease (AD)-From concept to clinical testing. J. Nutr. Health Aging 2009, 13, 264-267. [CrossRef]

128. Nelde, A.; Rammensee, H.G.; Walz, J.S. The Peptide Vaccine of the Future. Mol. Cell. Proteom. 2021, 20, 100022. [CrossRef] [PubMed]

129. Birmpilis, A.I.; Karachaliou, C.E.; Samara, P.; Ioannou, K.; Selemenakis, P.; Kostopoulos, I.V.; Kavrochorianou, N.; Kalbacher, H.; Livaniou, E.; Haralambous, S.; et al. Antitumor Reactive T-Cell Responses Are Enhanced In Vivo by DAMP Prothymosin Alpha and Its C-Terminal Decapeptide. Cancers 2019, 11, 1764. [CrossRef]

130. Zhai, P.; Ding, Y.; Wu, X.; Long, J.; Zhong, Y.; Li, Y. The epidemiology, diagnosis and treatment of COVID-19. Int. J. Antimicrob. Agents 2020, 55, 105955. [CrossRef]

131. Armstrong, R.A. Risk factors for Alzheimer's disease. Folia Neuropathol. 2019, 57, 87-105. [CrossRef]

132. Ogino, S.; Nowak, J.A.; Hamada, T.; Milner, D.A., Jr.; Nishihara, R. Insights into Pathogenic Interactions among Environment, Host, and Tumor at the Crossroads of Molecular Pathology and Epidemiology. Annu. Rev. Pathol. 2019, 14, 83-103. [CrossRef] [PubMed]

133. Willyard, C. How gut microbes could drive brain disorders. Nature 2021, 590, 22-25. [CrossRef] [PubMed]

134. Chen, S.G.; Stribinskis, V.; Rane, M.J.; Demuth, D.R.; Gozal, E.; Roberts, A.M.; Jagadapillai, R.; Liu, R.; Choe, K.; Shivakumar, B.; et al. Exposure to the Functional Bacterial Amyloid Protein Curli Enhances Alpha-Synuclein Aggregation in Aged Fischer 344 Rats and Caenorhabditis elegans. Sci. Rep. 2016, 6, 34477. [CrossRef] [PubMed]

135. Ashton, N.J.; Janelidze, S.; Al Khleifat, A.; Leuzy, A.; van der Ende, E.L.; Karikari, T.K.; Benedet, A.L.; Pascoal, T.A.; Lleó, A.; Parnetti, L.; et al. A multicentre validation study of the diagnostic value of plasma neurofilament light. Nat. Commun. 2021, 12, 3400. [CrossRef] [PubMed]

136. Wongta, A.; Hongsibsong, S.; Chantara, S.; Pattarawarapan, M.; Sapbamrer, R.; Sringarm, K.; Xu, Z.L.; Wang, H. Development of an Immunoassay for the Detection of Amyloid Beta 1-42 and Its Application in Urine Samples. J. Immunol. Res. 2020, 2020, 8821181. [CrossRef] [PubMed]

137. Razzino, C.A.; Serafín, V.; Gamella, M.; Pedrero, M.; Montero-Calle, A.; Barderas, R.; Calero, M.; Lobo, A.O.; Yáñez-Sedeño, P.; Campuzano, S.; et al. An electrochemical immunosensor using gold nanoparticles-PAMAM-nanostructured screen-printed carbon electrodes for tau protein determination in plasma and brain tissues from Alzheimer patients. Biosens. Bioelectron. 2020, 163, 112238. [CrossRef] [PubMed]

138. Nakamura, A.; Kaneko, N.; Villemagne, V.L.; Kato, T.; Doecke, J.; Doré, V.; Fowler, C.; Li, Q.X.; Martins, R.; Rowe, C.; et al. High performance plasma amyloid- $\beta$ biomarkers for Alzheimer's disease. Nature 2018, 554, 249-254. [CrossRef] 